\title{
Cardiology in the Young
}

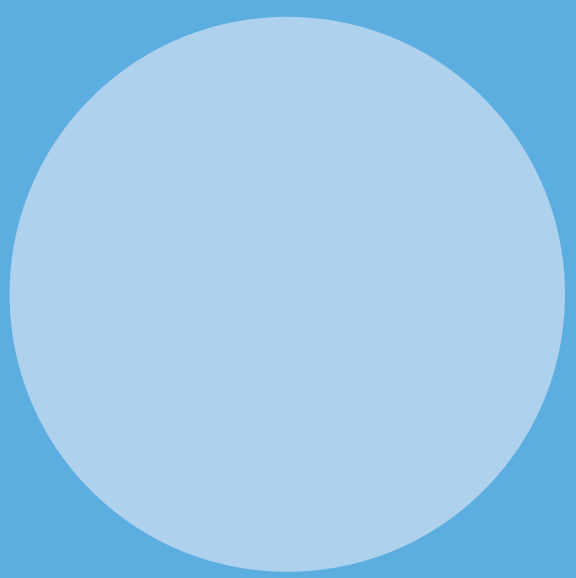

Cardiology in the Young $45^{\text {th }}$ Annual Meeting of the Association for European Paediatric Cardiology, AEPC with joint sessions with the Japanese Society of Pediatric Cardiology and Cardiac Surgery Granada, Spain, May 18-21, 2011

Supplement Editor: Dr. Maria del Mar Rodríguez Vázquez del Rey

Servicio de Pediatria Hospital Universitario Virgen de Las Nieves Granada, Spain 


\title{
Cardiology in the Young
}

journals.cambridge.org/CTY

\section{Editor-in-Chief}

Professor Edward J. Baker

Oxford Radcliffe Hospitals NHS Trust, John Radcliffe Hospital, Headington, Oxford, OX3 9DU, UK

\section{Emeritus Founding Editor}

Professor Robert H. Anderson

Cardiac Unit, Institute of Child Health, University College London,

30 Guilford Street, London WC1N 1EH, UK

\begin{abstract}
Associate Editors
Allen D. Everett, Baltimore, MD

Jeffrey P. Jacobs, St Petersburg, FL
\end{abstract}

\section{International Editors}

G. William Henry, Chapel Hill, NC

Hiromi Kurosawa, Tokyo

Supplements Editor Jeffrey P. Jacobs, St Petersburg, FL

Images Editor

Roxane McKay, Memphis, TN

Founding Editors

Anton E. Becker, Amsterdam; Giancarlo Crupi, Bergamo; Arthur Garson Jr, Charlottesville, VA; Fernando Lucchese, Porto Alegre; Lucio Parenzan, Bergamo; the late Atsuyoshi Takao, Tokyo; Michael Tynan, London

$\begin{array}{ll}\begin{array}{l}\text { International Editorial Board } \\ \text { Lindsey D. Allan (London) }\end{array} & \\ \text { Maurice Beghetti (Geneva) } & \text { Luc Mertens (Toronto) } \\ \text { Lee N. Benson (Toronto) } & \text { Cleonice de C. Mota (Belo Horizonte) } \\ \text { Per G. Bjørnstad (Oslo) } & \text { Jane Newburger (Boston, MA) } \\ \text { Anthony C. Chang (Orange, CA) } & \text { Edgardo E. Ortiz (Quezon City) } \\ \text { Tjark Ebels (Groningen) } & \text { Daniel Penny (Melbourne) } \\ \text { Timothy Feltes (Columbus, OH) } & \text { Andrew N. Redington (Toronto) } \\ \text { J. William Gaynor (Philadelphia, PA) } & \text { Girish S. Shirali (Charleston, SC) } \\ \text { Allan Goldman (London) } & \text { Giovanni Stellin (Padova) } \\ \text { Willem A. Helbing (Rotterdam) } & \text { András Szatmári (Budapest) } \\ \text { John Hess (Munich) } & \text { Hideki Uemura (London) } \\ \text { Eero Jokinen (Helsinki) } & \text { Steven A. Webber (Pittsburgh, PA) } \\ \text { Tom Karl (Brisbane) } & \text { James L. Wilkinson (Melbourne) } \\ \text { Doff B. McElhinney (Boston, MA) } & \text { Shi-Joon Yoo (Toronto) }\end{array}$

Cardiology in the Young is indexed and abstracted in Index Medicus/MEDLINE; Current Contents/Clinical Medicine; Research Alert; Sci Search; EMBASE/Excerpta Medica 


\section{The Organising Committee}

\section{Local Committee}

\section{President}

Mª del Mar Rodríguez Vázquez del Rey

\section{Honorary President}

Ramón Bermudez-Cañete Fernández

\section{Members}

Julio Romero González

Dimpna Albert Brotons

Francesca Perin

Carlos Briales Casero

\section{Scientific Committee}

Shakeel Qureshi

Eero Jokinen

Joseph de Giovanni

Jörg Stein

André Bozio

Ramón Bermudez-Cañete

María del Mar Rodríguez

Katarina Hanseus

Konrad Brockmeier

Juan Comas

Georgia Sarquella-Brugada

\section{Committee members of JSPCCS 2011}

Toshio Nakanishi

Hideaki Kado

Makoto Nakazawa

Toshiaki Yagihara

Tsutomu Saji

Shunichi Ogawa

Kisaburo Sakamoto

Koichiro Niwa

Shunji Sano

\section{Conference Secretariat}

Opening hours

Wednesday

Thursday

Friday

Saturday
18.05.2011

19.05.2011

20.05 .2011

21.05 .2011
07:30-18:30

07:30-18:30

07:30-18:30

08:00-14:00

PCO \& Medical exhibition

Viajes Iberia Congresos

Ms. Ana Lora

Ronda de Capuchinos, 4 - Bloque 3 - Local 3-4 - 41003 Sevilla (Spain)

Tel.: + 34954224095

Fax.: +34954210215

email: ana.lora@viajesiberia.com

www.viajesiberiacongresos.com

www.aepc2011.com

\section{Venue}

Granada Congress \& Exhibition Centre,

Paseo del Violón s/n, 18006 Granada, Spain.

www.pcgr.org 


\section{Sponsors and Exhibitors:}

The AEPC would like to give special thanks to all Sponsors and Exhibitors of the 45th Annual Meeting.

ABBOT LABORATORIES S.A.

AGA MEDICAL/ST. JUDE MEDICAL

BAYER

EDWARDS LIFESCIENCES

GE HEALTHCARE

MEDTRONIC

NUMED/EVOMED

OCCLUTECH INTERNATIONAL AB

OSYPKA AG

PFM MEDICAL

SERENAS GROUP

SIEMENS AG

UT UNITED TERAPEUTICS

VENTRIPOINT

W.L. GORE Y ASOCIADOS, S.L.

WISEPRESS

ZENICOR MEDICAL SYSTEMS

PFIZER 


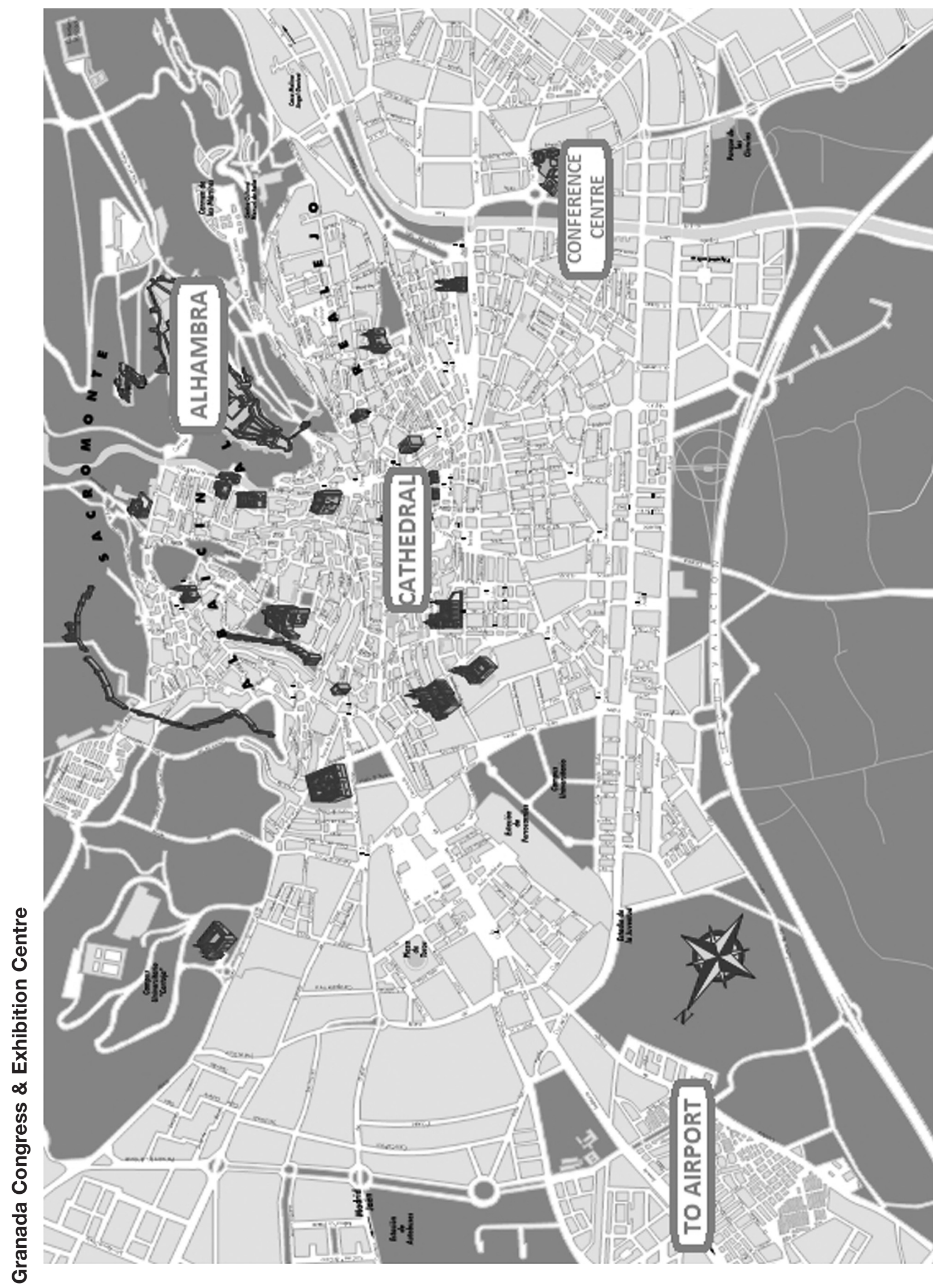


FLOOR 1

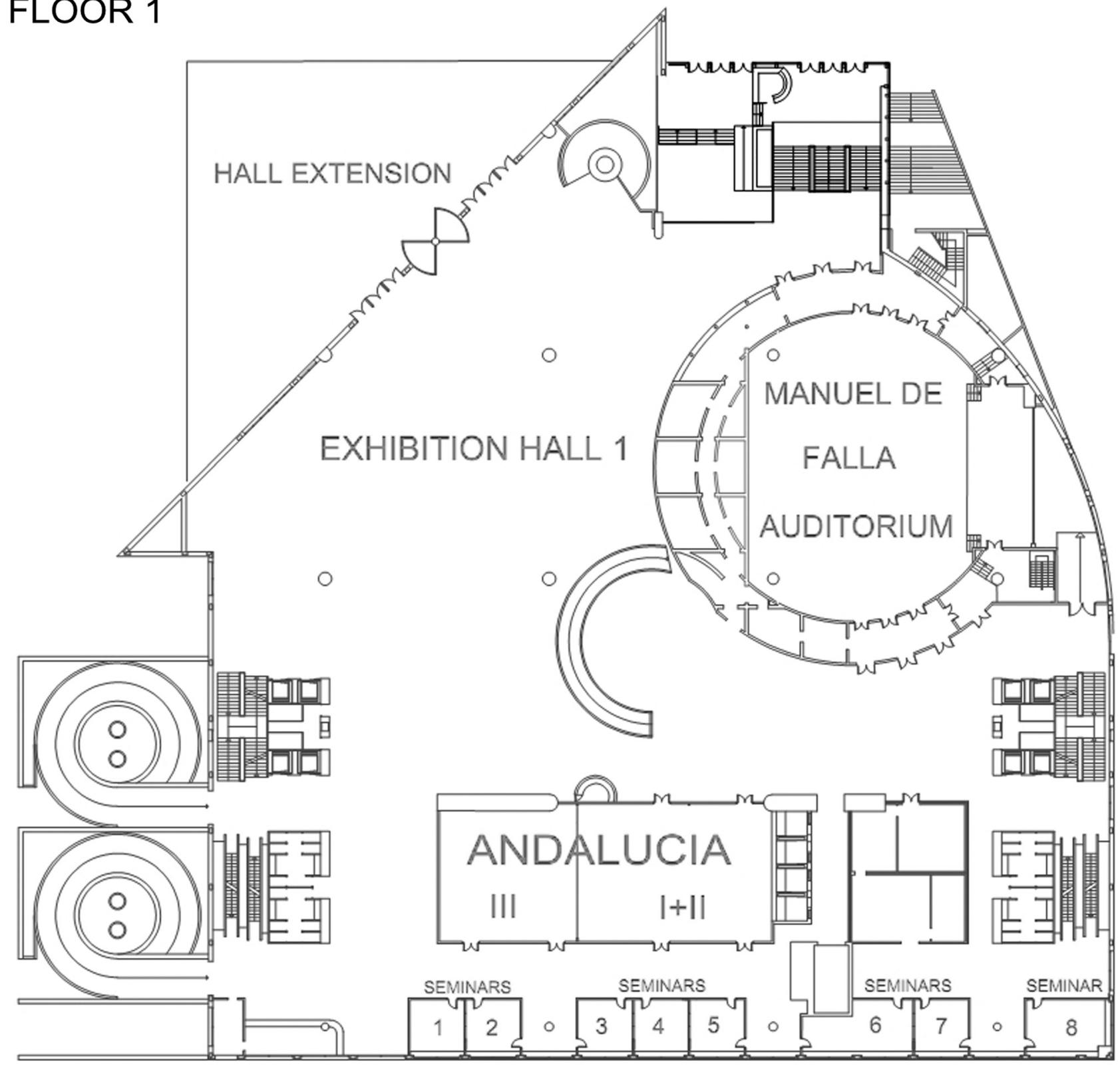




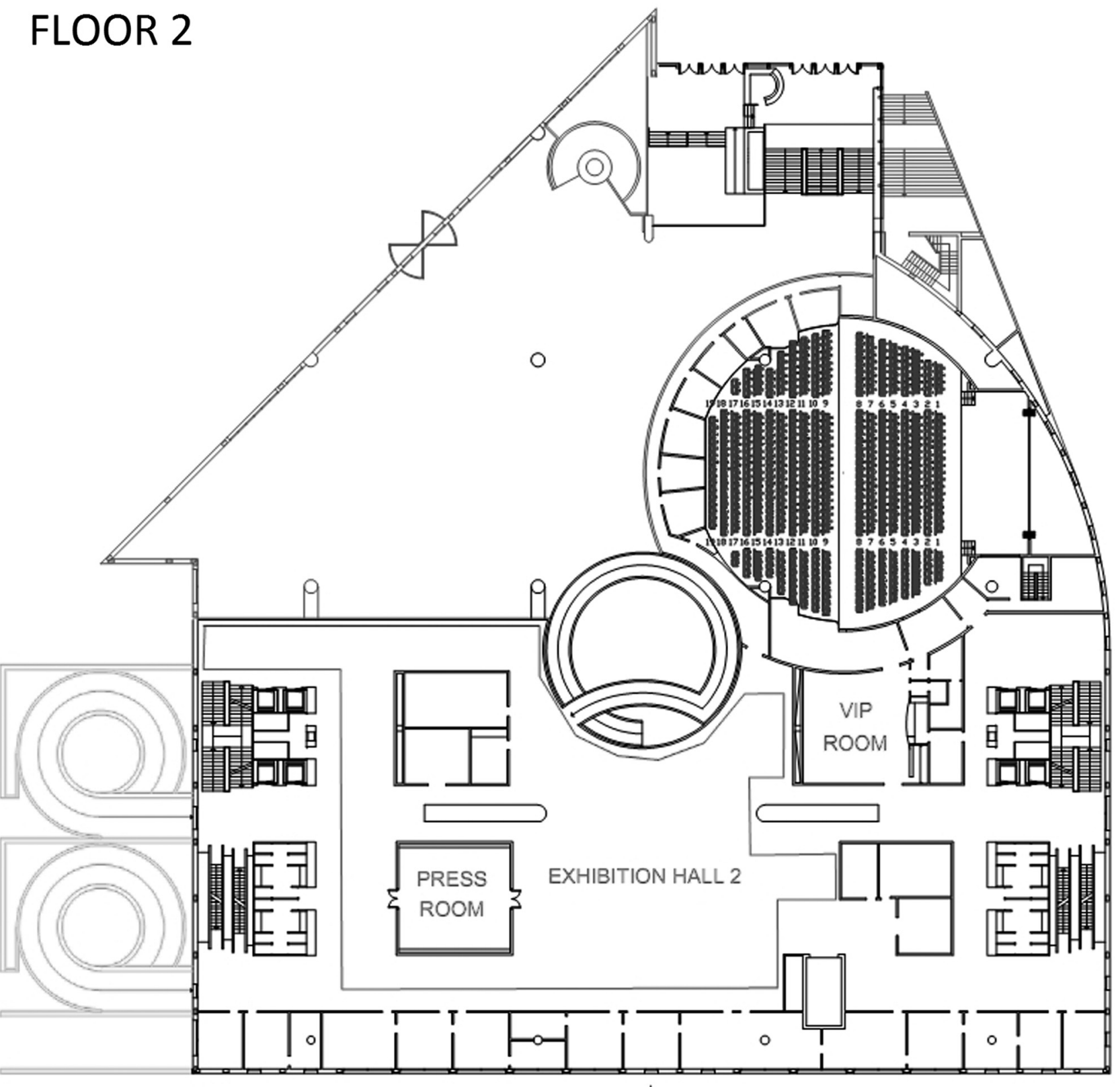




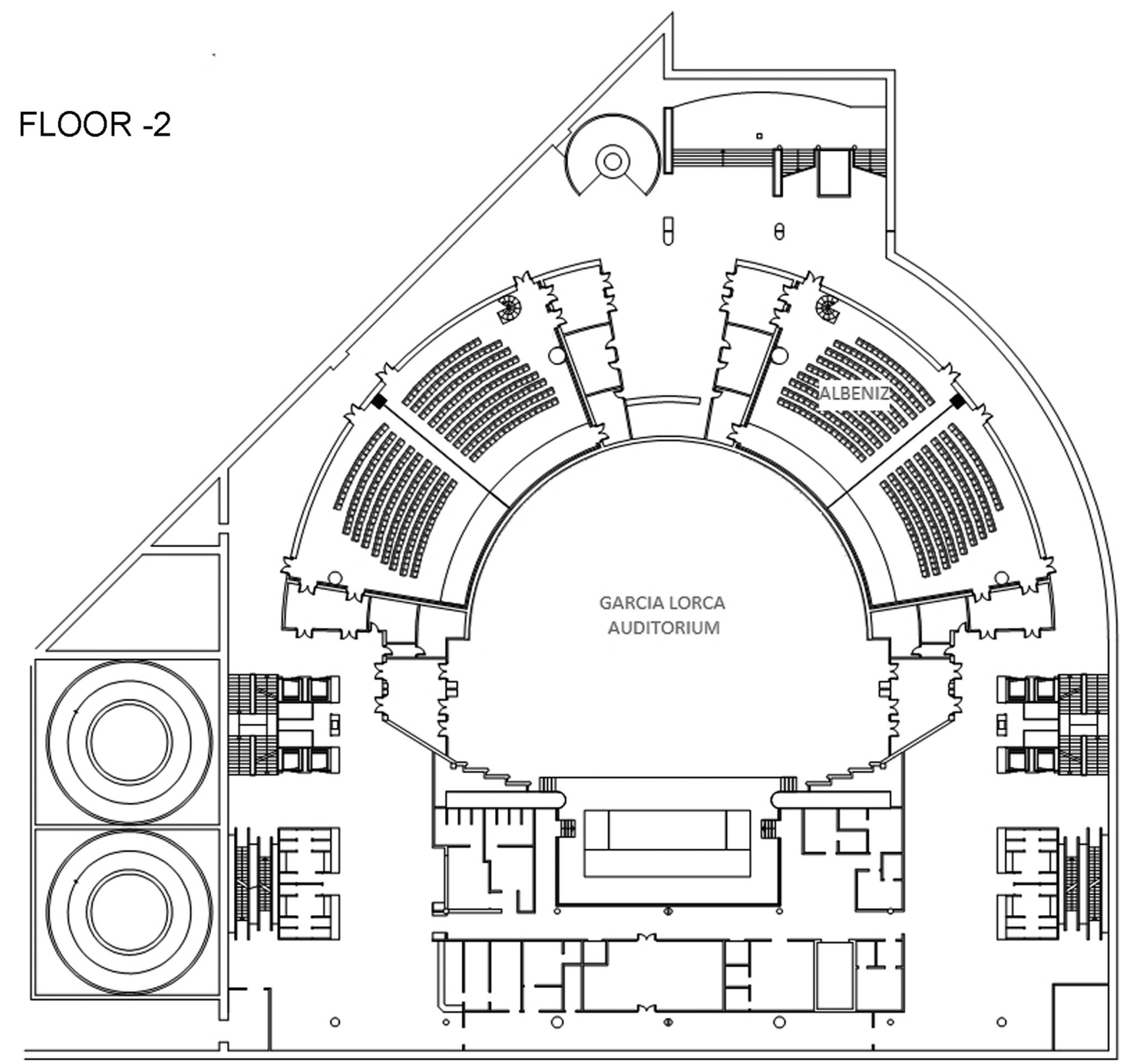




\section{Agenda AEPC Business Meeting Granada Manuel de Falla Auditorium, Thursday, 19 May, 2011 18:00-20:30}

1. Welcome address by the President (Shak Qureshi)

2. Obituary

3. Report of the President

4. Report of the Secretary-General

5. Report of the Scientific Secretary

6. Report of the Treasurer

7. New name of the Association

(Shak Qureshi)

8. Amendments in the Constitution

(E. Jokinen)

(J. deGiovanni)

(J. Stein)

(E. Jokinen)

9. News from the Working Groups

Cardiac Dysrhythmias and Electrophysiology

(E. Jokinen)

Fetal Cardiology

Basic Genetics of Congenital Heart Defects

Pediatric Cardiovascular Intensive Care

N. Blom

M. Melander

I. Frohn-Mulder

E. Lechner

Cardiac Imaging

J. Marek

Interventional Cardiology

Cardiovascular Morphology

G. Brzezinska-Rajszys

Congenital Heart Surgery

A. Angelini

B. Maruszewski

Psycho-Social care from fetus to adult

F. Casey

GUCH Task Force

A. Szatmári

Preventive Cardiology

10. Report from the Advisory Board/National Delegates

11. Introduction of New Members

(E. Jokinen)

12. Replacement of Council member

(E. Jokinen)

13. Future Meetings:

(E. Jokinen)

2012 Istanbul

2013 London

2014 Helsinki

14. Other business?

\section{ADDENDUM:}

\# 7. The Council proposes that the name of the Association should be changed to

Association for European Paediatric and Congenital Cardiology (AEPC)

Association Européenne de Cardiologie Pédiatrique et Congénitale. (AEPC)

The current name is

Association for European Paediatric Cardiology (AEPC)

Association Européenne de Cardiologie Pédiatrique (AEPC)

\#8. The council proposes following changes in the Constitution

a) The Council proposes that the following sentence should be added in the Constitution

"When deemed appropriate by the AEPC Council, the Council will have the right, by majority vote, to co-opt additional members on to the Council to represent specific subspecialty groups (not already represented on the Council) for a maximum period of 3 years."

b) "Chairman of the Educational Committee shall be an ex-officio member of the Professional Advisory Committee" 


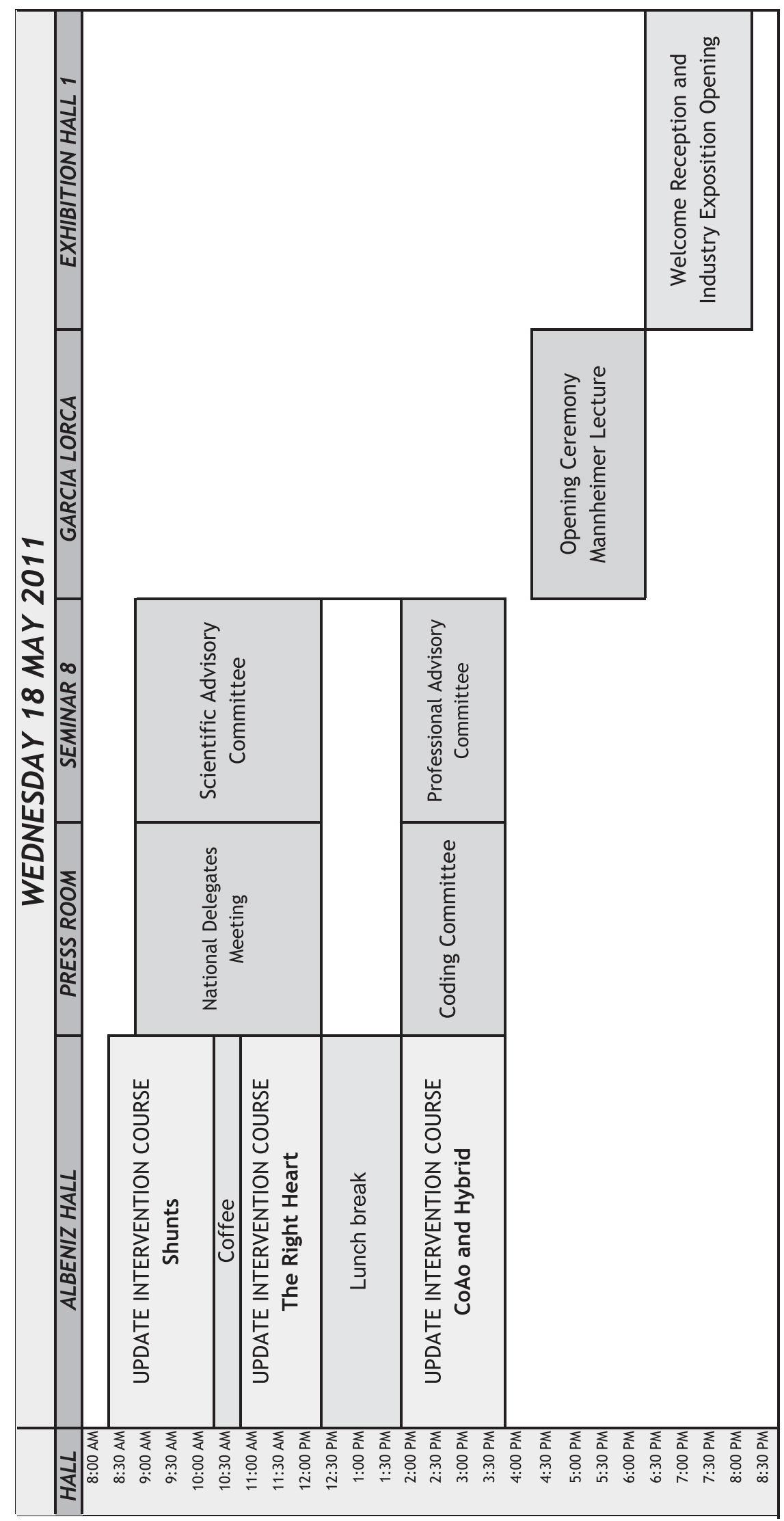




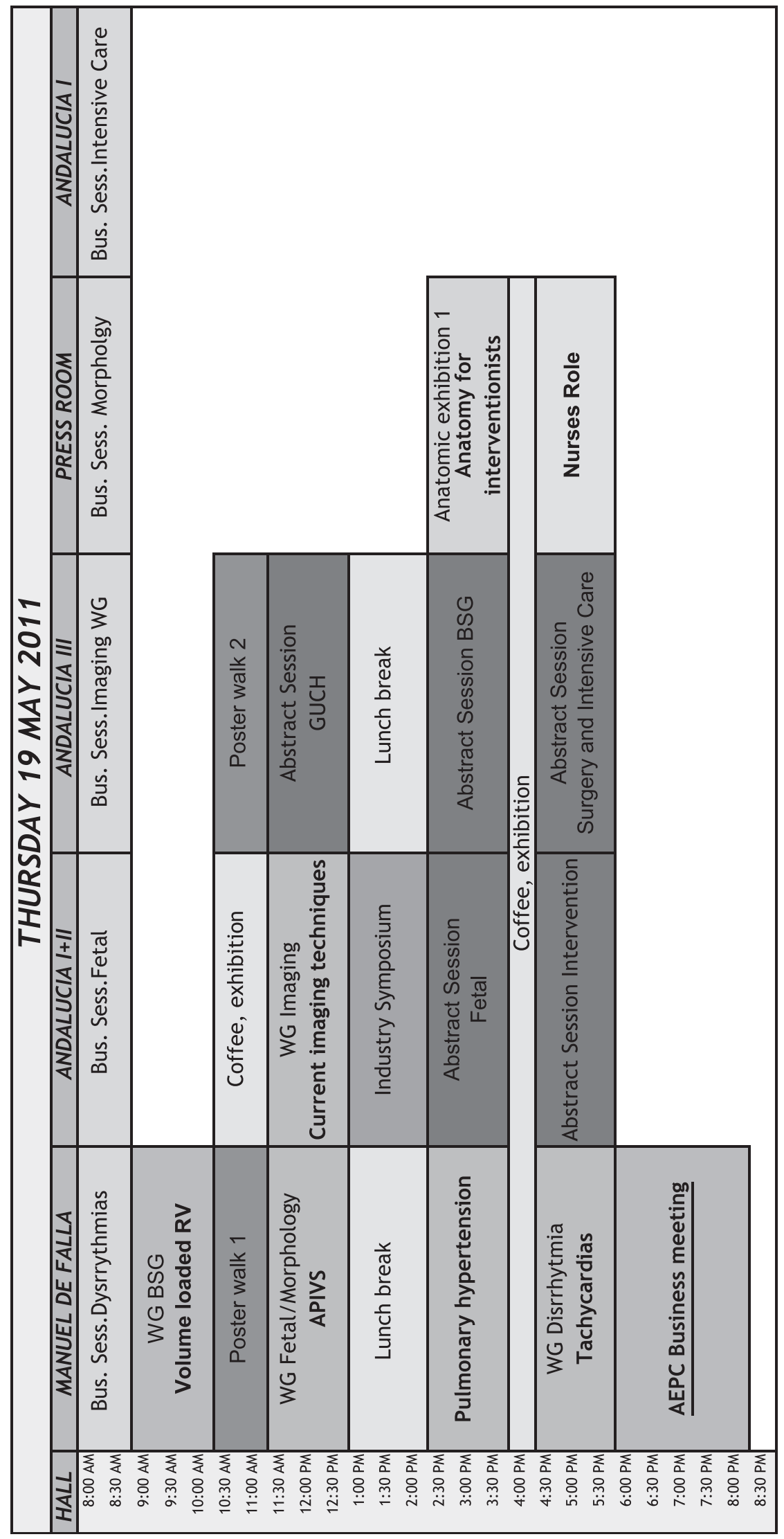




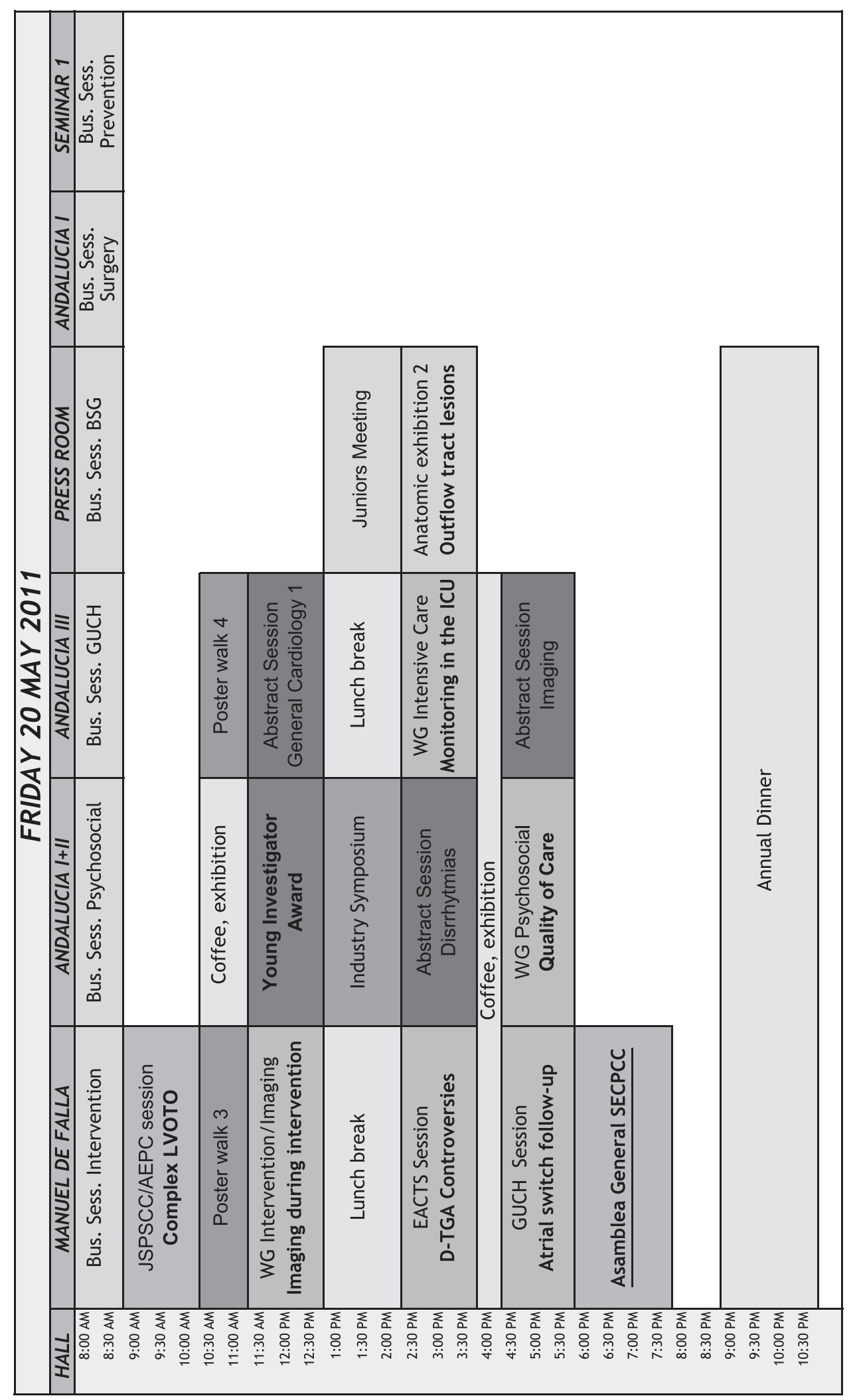




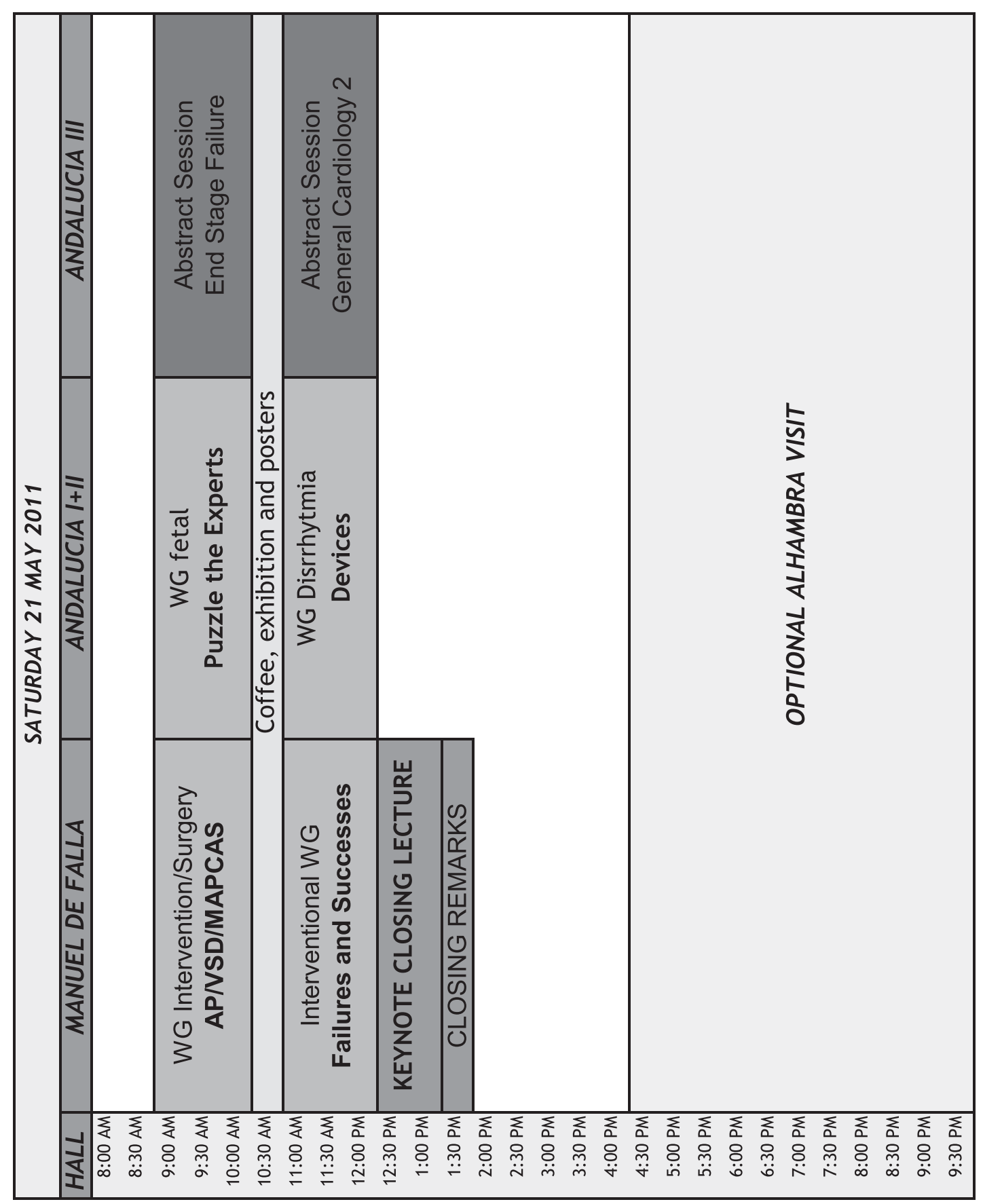




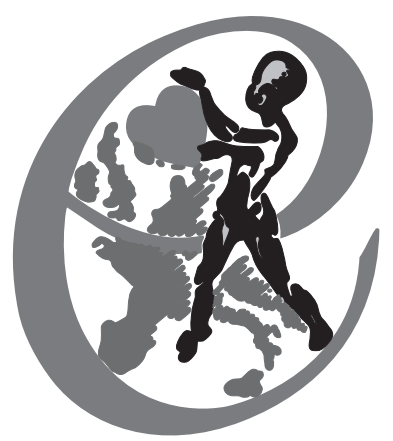

45th Annual Meeting of the

Association for European Paediatric Cardiology,

AEPC with joint sessions with the

Japanese Society of Pediatric Cardiology and

Cardiac Surgery, Granada, Spain

May 18-21, 2011

SCIENTIFIC PROGRAMME

8:30-15:30

Albeniz Hall

08:30-10:15

Albeniz Hall

08:30

08:45

09:05

09:25

09:45

10:15-10:45

Dining Hall

10:45-12:30

Albeniz Hall

$10: 45$

11:00

$11: 20$

$11: 32$

$11: 44$

$11: 56$

12:30-13:45

Dining Hall

13:45-15:30

Albeniz Hall

$13: 45$

14:00
WEDNESDAY, MAY 18, 2011

\section{UPDATE INTERVENTION COURSE}

\section{Update Intervention Course: Shunts}

Chair: Mario Carminati (Milano, IT), Maarten Witsenburg (Rotterdam, NL)

Introduction

Challenging arterial ducts

Nikolaus Haas

Difficult ASDs

John Thomson

Complex VSDs

Gianfranco Butera

Other shunts

Fredy Prada

Coffee break

Update Intervention Course: The right heart

Chair: Shakeel Qureshi (London, UK), Marc Gewillig (Leuven, BE)

Introduction

PA stenosis

Caroline Ovaert

Palliative pulmonary blood flow: Neonatal duct stenting (not in HLHS)

Dietmar Schranz

Palliative pulmonary blood flow: Stent expansion of shunts

Derize Boshoff

Palliative pulmonary blood flow: RVOT stenting in neonates

Ingo Daehnert

Percutaneous pulmonary valve implantation

Andreas Eicken

Lunch

Update Intervention Course: CoAo and hybrid

Chair: Jo de Giovanni (Birmingham, UK), Grazyna Brzezinska-Rajszys (Warsaw, PL)

Introduction

Coarctation: Simple coarctation

Rui Anjos 


\begin{tabular}{|c|c|}
\hline 14:20 & $\begin{array}{l}\text { Coarctation: Complex aortic narrowing } \\
\text { Maria Zubrzycka }\end{array}$ \\
\hline $14: 40$ & $\begin{array}{l}\text { Hybrid procedures in HLHS } \\
\text { Ina Michel-Behnke }\end{array}$ \\
\hline 15:00 & $\begin{array}{l}\text { Outlook on new procedures } \\
\text { Peter Ewert }\end{array}$ \\
\hline $\begin{array}{l}9: 00-12: 30 \\
\text { Seminar } 8\end{array}$ & Scientific Advisory Committee \\
\hline $\begin{array}{l}\text { 14:00-16:00 } \\
\text { Press room }\end{array}$ & Coding Committee \\
\hline $\begin{array}{l}\text { 9:00-12:30 } \\
\text { Press room }\end{array}$ & National Delegates Meeting \\
\hline $\begin{array}{l}\text { 14:00-16:00 } \\
\text { Seminar } 8\end{array}$ & Profesional Advisory Committee \\
\hline $\begin{array}{l}\text { 16:00-18:00 } \\
\text { Garcia Lorca }\end{array}$ & $\begin{array}{l}\text { Opening Ceremony } \\
\text { Chair: Ramón Bermudez-Cañete (Madrid, ES) } \\
\text { Chair: Maria del Mar Rodríguez (Granada, ES) }\end{array}$ \\
\hline 16:00 & $\begin{array}{l}\text { Mannheimer lecturer } \\
\text { Charles E.Mullins }\end{array}$ \\
\hline $\begin{array}{l}\text { 18:00-20:00 } \\
\text { Exhibition Hall } 1\end{array}$ & Welcome reception \\
\hline
\end{tabular}

THURSDAY, MAY 19, 2011

08:00-09:00

Andalucia III room

08:00-09:00

Manuel de Falla

08:00-09:00

Press room

08:00-09:00

Andalucia I+ II room

08:00-09:00

Seminar 8

09:00-10:30

Manuel de Falla

09:00

09:15

09:30

09:45

10:00

10:30-11:30

Exhibition Hall 1

10:30-11:30

Exhibition Hall 1

10:30

PW1-1
WG Business Meeting: Cardiac Imaging

WG Business Meeting: Cardiac Dysrhythmia and Electrophysiology

WG Business Meeting: Cardiovascular Morphology

WG Business Meeting: Fetal Cardilogy

WG Business Meeting: Paediatric cardiovascular Intensive care

The volume loaded RV

Chair: Antonia Pijuan (Barcelona, ES), Beatrijs Bartelds (Groningen, NL)

RV development and remodeling

Adriana Gittenberger de Groot

$\mathrm{RV}$ adaptation to volume load

Beatrijs Bartelds

The role of the LV in RV volume load: LV/RV interactions

Toshio Nakanishi

How big is too big? - clinical assessment of the volume loaded RV

Marina Hughes

Round table discussion

Coffee Break, Exhibition

\section{Poster Walk 1}

Stent recanalization of occluded iliofemoral and inferior cava veins in children with congenital heart disease: Acute and mid-term results Álvarez Fuente M., Zunzunegui J.L., Ballesteros F., Rodriguez Ogando A., Camino M., Maroto E. 
10:35

PW1-2

10:40

PW1-3

10:45

PW1-4

10:50

PW1-5

10:55

PW1-6

11:00

PW1-7

11:05

PW1-8

11:10

PW1-9

11:15

PW1-10

11:20

PW1-11

11:25

PW1-12

10:30-11:30

Exhibition Hall 1

10:30

PW2-1

10:35

PW2-2

10:40

PW2-3

10:45

PW2-4

10:50

PW2-5

10:55

PW2-6
Double wire/double balloon/single stent delivery technique broadens interventional possibilities in challenging targets

Gewillig M., Boshoff D.E., Cools B., Louw J.J., Vanagt W., Eyskens B., Heying R., Budts W. Percutaneous Fenestration Closure using the Amplatzer Ductus Occluder II - Increasing the Experience

Granja S., Vazquez M.C., Centeno M., Medrano C., Álvarez T.,

Ballesteros F., Maroto E., Zunzunegui J.L.

Percutaneous pulmonary valve replacement in bovine jugular vein grafts (Contegra ${ }^{\mathrm{TM}}$ ) -

Anything fancy?

Kretschmar O., Dave H., Prêtre R., Knirsch W.

Growth of the Right Ventricle following an Aggressive Approach to Catheter Valvotomy in

Pulmonary Atresia with Intact Ventricular Septum

Chubb H., Pesonen E., Sivasankaran S., Simpson J.M., Krasemann T.,

Rosenthal E., Tibby S.M., Qureshi S.A.

Percutaneous treatment of aortic isthmus atresia: use of radiofrequency perforation and

covered stents

Butera G., Heles M., McDonald ST., Papa M., Piazza L., Chessa M., Micheletti A., Negura D., Arcidiacono C., Bussadori C., Carminati M.

Does presence of ventricular septal defect influence survival after arterial switch operation for transposition of the great arteries?

Mussa S., Stickley J., Barron D.J., Jones T.J., Brawn W.J.

Does neonatal cardiac surgery influence the balance between vasodilative and

vasoconstrictive mediators?

Marcinkowski V., Schumacher K., Terrada E., Buding B., Vazquez-Jimenez J., Seghaye M-C

Propofol effect on cerebral oxygenation and cardiac output in children with congenital heart defects before cardiac catheterization

Fleck T., Nagdyman N., Schubert S., Ewert P., Stiller B., Berger F.

Fluctuations of Intraoperative Near Infra Red Spectroscopy During Neonatal and Infant

Congenital Heart Surgery According to Defect Physiology, Bypass and Modified

Ultrafiltration

Gottschalk U., Osse J., Eulenburg C., Goepfert M., Wendt U., Reichenspurner H., Dodge-Khatami A.

Home surveillance program clearly reduces interstage mortality after the Norwood operation for patients with Hypoplastic left heart syndrome

Furck A.K., Hansen J.-H., Petko C., Buchholz-Berdau R., Scheewe J., Kramer H.H.

Branch pulmonary artery flow reversal: Does it correlate with

valve leak?

Gist K., Panwar S., Landeck B., Mitchell M.

\section{Poster Walk 2}

Acquired Right Ventricle Outflow Tract Obstruction in Twin-Twin Transfusion Syndrome Alvarez T., Marcos C., Antolin E., Perez Pacheco R., Ballesteros F., Zunzunegui J.L., Maroto E. Outcome of Hypoplastic Left and Right Heart Syndrome (HLHS and HRHS) after antenatal diagnosis in South Wales over a seven year period

Uzun O., Neenakantan G., Sinha A.

Aortic Stenosis and Severe Mitral Regurgitation in the Fetus Resulting in Giant Left Atrium and Hydrops: Pathophysiology, Outcomes, and Preliminary Experience with Prenatal Cardiac Intervention

Vogel M., McElhinney D.B., Wilkins-Haug L., Marshall A., Benson C.B., Lock J.E.,

Schranz D., Tworetzky W.

Natural course of right ventricular dilation in severe pulmonary regurgitation after repair of tetralogy of Fallot

Navarini S., Moccetti M., Kellenberger Ch., Valsangiacomo Buechel E.R.

Endothelial function in Kawasaki patients

Paramés F., Cortez-Dias N., Freitas I., Mota-Carmo M, Ferreira R.C., Pinto F.F.

Echocardiographic Assessment of Right Ventricular Volumes: A Comparison of Different

Techniques in Children after Surgical Repair for Tetralogy of Fallot

Dragulescu A., Grosse-Wortmann L., Fackoury C., Riffle S., Waiss M.-P., Jaeggi E., Yoo S.J., Friedberg M.K., Mertens L. 
11:00

PW2-7

11:05

PW2-8

11:10

PW2-9

11:15

PW2-10

11:20

PW2-11

11:25

PW2-12

11:30-13:00

Manuel de Falla

$11: 30$

11:45

12:00

12:15

$12: 30$

11:30-13:00

Andalucia I+II room

$11: 30$

$11: 45$

12:00

12:15

$12: 30$

11:30-13:00

Andalucia III room

$11: 30$

01-1

$11: 42$

01-2
Ventricular flow dynamics in hypoplastic left heart: useful insights from patient specific computer modelling de Vecchi A., Bellsham-Revell H., Smith N., Simpson J.M., Razavi R., Greil G.

Right ventricular systolic function after Tetralogy of Fallot repair revisited: Does the outflow tract matter?

Alghamdi M.H., Mertens L., Lee W., Yoo S.J.,Grosse-Wortmann L.

Development and validation of a novel automated learning based algorithm for quantification of MRI right ventricular volume in Tetralogy of Fallot

Spevak P.J., Ionasec R., Mansi T., Holmes K., Pongiglione G, Everett A.

New Steady State Submaximal Exercise Test during Cardiovascular Magnetic Resonance First Results in Healthy Volunteers

Steinlechner E., Fratz S., Rieger H., Meierhofer C., Hager A., Mueller J., Martinoff S., Hess J., Stern H.

Safety and Clinical Utility of Cardiovascular Magnetic Resonance in Neonates with Congenital Heart Disease

Schaetzle B., Kellenberger C.J., Schmitz A., Hug M., Valsangiacomo Buechel E.R. Selective pulmonary venous flow visualization and quantification by flow-sensitive fourdimensional cine magnetic resonance imaging facilitates and improves the accurate diagnosis of partial anomalous pulmonary venous drainage Nordmeyer S., Berger F., Kuehne T., Riesenkampff E.

PAIVS-new aspects on fetal diagnosis and management

Chair: Sally Ann Clur (Amsterdam, NL), Monique Jongbloed (Leuven, NL)

Epidemiology of critical PS and PAIVS: overview of prevalence, diagnosis, management and outcome

Piers Daubeney

Mophological variance and secondary heart field: role of the coronary circulation in determining surgical management

Adriana Gittenberger de Groot

Managing the fetus and neonate with critical PS or PAIVS: appropriate selection of cases for a univentricular or biventricular circulation

The cardiologist's approach

Björn Söderberg

The surgeon's approach

Christian Schreiber

Round table discussion

Imaging Modalities - Current and future blessings

Chair: Jan Marek (London, UK), Ornella Milanesi (Padua, IT)

When and which modality I use in clinical practice

John Simpson

Deformation techniques - concept, value and pitfalls

Andreea Dragulescu

Future developments: 3D wall tracking, MRI tagging, 4D flow

Philipp Beerbaum

CMR-helpful, indispensible but it is always right?

Joachim Eichhorn

Round table discussion

\section{Abstract Session $1 \mathrm{GUCH}$}

Chair: Erik J. Meijboom (Laussane, CH), Koichiro Niwa (Tokyo, JP)

Quality of Life, Psychosocial Adjustment, Psychiatric Morbidity, School Performance, Physical Limitations and Social Support in Adolescents and Young Adults with Congenital Heart Disease: How these variables play together?

Teixeira F., Coelho R., Proença C., Silva A.M., Vieira D., Vaz C., Moura C., Viana V., Areias J.C., Areias M.E.G.

Sense of coherence in adolescents with congenital heart disease in the transition to adulthood

Goossens E., Loiacono A., Luyckx K., Gewillig M., Budts W., Moons P. 
11:54
$01-3$
$12: 06$
$01-4$

$12: 18$
$01-5$
$12: 30$
$01-6$

$12: 42$
$01-7$

13:00-14:30

Exhibition Hall 2

14:30-16:00

Manuel de Falla

14:30

14:45

15:00

15:15

$15: 30$

14:30-16:00

Andalucia III room

14:30

O2-1

$14: 42$

$\mathrm{O} 2-2$

$14: 54$

O2-3

15:06

O2-4

$15: 18$

O2-5

15:30

O2-6
Transition from pediatric cardiology to GUCH-information from the Swedish National Registry SWEDCON

Björkhem G., Thilén U.

Risk stratification for congenital heart surgery in adults - Are the Aristotle Complexity score models appropriate?

Hörer J., Vogt M., Brenguier V., Rau M., Wottke M.,

Cleuziou C., Prodan Z., Kasnar-Samprec J., Schreiber C., Lange R.

Pulmonary Arterial Hypertension in adults with Isolated Atrial Septal Defects

Roofthooft M.T.R., Bartelds B., Pricker K., Kerstjens-Frederikse W.S.,

Vos Y.J., Meijboom F.J., Berger R.M.F.

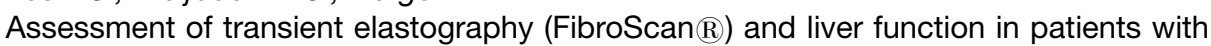

Fontan circulation

Donner B.C., Yazdi S.F., Bohnen K., Kircheis G., Oh J., Donner M.G., Häussinger D., Schmidt K.G.

Neoaortic root in children with transposition of the great arteries (TGA) after arterial switch operation (ASO)

Michalak K.W., Moll J.A, Młudzik K., Moll M., Moszura T., Kopala M., Moll J.J.

\section{Lunch}

Pediatric pulmonary hypertension: What are we doing and what should be done to improve the outcome of these patients?

Chair: Ornella Milanese (Padua, IT), Oliver Miera (Berlin, DE)

The value of a register for orphan diseases

Maurice Beghetti

Organization of care: The UK National Service for Pulmonary Hypertension in Children: organisation of care, results of drug treatments, areas of research

Ingram Shulze-Neick

Spanish register for pediatric pulmonary hypertension: REHIPED

Maria Jesus del Cerro (Pulmonary Circulation Working Group, SECPCC)

Paediatric pulmonary hypertensive vascular disease: Suggestion for a novel paediatric classification

lan Adatia

Round table discussion

\section{Abstract Session 2 Genetics and Basic Science of Congenital Heart \\ Disease}

Chair: Patrice Bouvagnet (Lyon, FR), Constancio Medrano (Madrid, ES)

Shox2 in Pacemaker and Epicardial Development

Hahurij N.D., Blom N.A., Meijlink F., Mahtab E.A.F., Wisse L.J., Bökenkamp R., Kolditz D.P., Schalij M.J., Poelmann R.E., Jongbloed M.R.M.,

Gittenberger-de Groot A.C.

Wall shear stress in the ascending aorta in patients with bicuspid aortic valves differs significantly from tricuspid aortic valves

Meierhofer C., Schneider E.P., Lyko C., Martinoff S., Markl M., Hess J., Stern H., Fratz S.

Array-CGH based detection of genomic imbalances in patients with heart defects as part of complex syndromes

Arndt A.-K., Klopocki E., Siebert R., Mundlos S., Kramer H.-H., Klaassen S., Caliebe A.

Prevalence of mutations in the RAS/MAPK signalling pathway in

pre-adolescent children with hypertrophic cardiomyopathy

Kaski J.P., Syrris P., Tartaglia M., Shaw A., Alapi K., Tome-Esteban M.T., Jenkins S.,

Ashworth M., Hammond P., McKenna W.J., Elliott P.M.

Hypothermia suppresses inflammation via NFkB and pSTAT3 signalling pathway in

stimulated microglial cells

Krauss A., Wollersheim S., Soltani P., Tong G., Berger F., Schmitt K.R.L.

Infection-Induced Coronary Dysfunction and Systemic Inflammation in Piglets Are

Dampened in Hypercholesterolemic Milieu

Liuba P., Birck M.M., Pesonen E., Odermarsky O., Hansen A.K., Frikke-Schmidt H, Heegaard P. 
15:42

O2-7

14:30-16:00

Andalucia I+II room

14:30

O3-1

14:42

O3-2

14:54

O3-3

15:06

O3-4

15:18

O3-5

15:30

O3-6

15:42

O3-7

14:30-16:00

Press room

16:00-16:30

Exhibition Hall 1

16:30-18:00

Manuel de Falla

16:30

16:45

17:00

$17: 15$

17:30

$17: 45$

16:30-18:00

Andalucia I+II room

16:30

04-1

$16: 42$

O4-2
Spontaneous baroreflex sensitivity in adult rats hypoxic neonatally

McIntosh M., Rohlicek C.V.

\section{Abstract Session 3 Fetal Cardiology}

Chair: Helena Gardiner (London, UK), Joanna Dangel (Warsaw, PL)

Ebstein's anomaly and tricuspid valve dysplasia: prognosis after diagnosis in utero

Barre E., Durand I., Hazelzet T., Cuillier F., Cohen L., Poinsot J., Vaillant MC., Blaysat G., Bourges Petit E., Maingourd Y., Vaksman G., David N.

Prenatal diagnosis of complex congenital heart disease - success and outcome: A 28-year retrospective study

Mivelaz Y., Lim K.I., Cender L.M., Duncan W.J., Tessier F., Sinclair B.G.,

Farquharson D.F., Barlow A.J., Mayer C., Skoll A.M., Potts J.E., Sandor G.G.S.

Features and outcomes of cases with laterality defects diagnosed in fetal life

Fesslova V., Brankovic J.

Comparison of Transplacental Treatment of Fetal Supraventricular Tachyarrhythmia with

Digoxin, Flecainide and Sotalol: Results of a

Non-randomized Multicenter Study

Jaeggi E., Carvalho J.S., de-Groot E., Api O., Clur S.-A., McCrindle B.,

Rammeloo L, Manlhiot C., Blom N.A.

Critical aortic stenosis at risk of hypoplastic left ventricle:has the time come for in utero fetal intervention?

Marantz P., Peña G.,Aiello H.,Trentacoste L., Granja M., Izbizki G., Azancot A.,

Otaño L.

Postnatal left ventricular performance in prenatally treated patients with critical aortic

stenosis and endocardial fibroelastosis

Tulzer G., Arzt W., Wertaschnigg D., Gitter R., Mair R.

Fetal coarctation of the aorta - can we predict who needs surgery?

Jowett V., Jowett V., Aparicio P., Seale A., Jicinska H., Gardiner H.M.

Anatomic exhibition 1: "Cardiac anatomy for interventionalists"

Chair: Adriana Gittenberger De Groot (Leiden, NL)

Annalisa Angelini

Georgia Sarquella Brugada

Coffee Break, Posters and Exhibition

Management of tachycardias in children with structurally normal hearts

Chair: Lazlo Korneyi (Budapest, HU), Jan Janousek (Prague, CZ)

Asymptomatic WPW syndrome

Luis Tercedor

Chronic supraventricular tachycardias

Fabrizio Drago

VT in structurally normal hearts

Naokata Sumitomo

Should every LQTS gene carrier be treated with beta blockers?

PRO

Nico Blom

CONTRA

Andreas Pflaumer

Round table discussion

\section{Abstract Session 4 Interventional Cardiology}

Chair: Andreas Eicken (Munich, DE), Rui Anjos (Lisbon, PT)

Percutaneous pulmonary valve implantation versus surgical implantation/replacement in patients with right ventricular outflow tract dysfunction

Dilber D., Eicken A., Hager A., Fratz S., Hörer J., Malcic I., Hess J.

Benefits of Stenting the Arterial Duct following Catheter Valvotomy for Pulmonary Atresia with Intact Ventricular Septum

Chubb H., Simpson J.M., Krasemann T., Tibby S.M., Rosenthal E., Qureshi S.A. 
16:54

O4-3

17:06

O4-4

$17: 18$

O4-5

17:30

04-6

$17: 42$

O4-7

16:30-18:00

Andalucia III room

16:30

O5-1

$16: 42$

05-2

16:54

O5-3

17:06

O5-4

17:18

05-5

17:30

O5-6

17:42

O5-7

16:30-18:00

Press room

16:30

16:45

17:00

$17: 15$

17:30

18:00-20:30

Manuel de Falla

08:00-09:00

Seminar 1

08:00-09:00

Manuel de Falla

08:00-09:00

Andalucia I+II room
Mid term outcome of arterial duct stenting: results of a multicentre study

Milanesi O., Russo M.G., Maschietto N., Marrone C., Gaio G., Calabrò R., Stellin G., Vida V.L., Padalino M.A., Santoro G.

Wire fractures in Solysafe $\mathbb{R}$ Septal Occluders - a single center experience

Riede F.T., Gielen S., Schuler G., Dähnert I.

Premounted low profile (PLP) Stents reexpandable with over size balloons to double its original diameter. An "In vitro" evaluation study of new vascular Stents before its use in Infancy Mortera C., Carretero J., Prada F.

Endovascular stenting in transverse aortic arch hypoplasia

Pushparajah K., Sadiq M., Brzezinska-Rajszys G., Thomson J., Rosenthal E., Qureshi S.A.

Non-invasive Cardiac Output Monitoring during Catheter Interventions in Patients with

Cavo-pulmonary Circulations

Stumper O., Noonan P., Chambers A., Viswanathan S.

Abstract Session 5 Surgery and Intensive Care

Chair: Evelyn Lechner (Linz, AT), Juan Miguel Gil Jaurena (Málaga, ES)

Perioperative Uncontrolled Pulmonary Hypertension Alters Long-Term Function And Durability Of Right-Sided Homografts Implanted In Ross And Non-Ross Patients

Kalfa D., Loundou A., Nouaille de Gorce Y., Fraisse A., Metras D., Macé L., Kreitmann B.

Patient age influences neoaortic root dimensions and aortic regurgitation following the Ross operation in children

Hörer J., Kasnar-Samprec J., Stierle U., Bogers A.J.J.C., Hemmer W., Hetzer R., Sievers H.H., Lange R.

Right Ventricular Outflow Reconstruction With Injectable Valve

Marianeschi S.M., Ghiselli S., Amodeo A., Suleymann O., Comas J.V., Santoro F., Lamas M.J., Parry E., Abruzzese P., Solana R., Abelleira C., Gómez R.

When Coronary Arteries Need Right Ventricular Systolic Pressure

Cools B., Moniotte S., De Wolf D., Dessy H., Sluysmans T., Gewillig M.

"Hybrid" palliation of Interrupted Aortic Arch as initial treatment modality

Chan K.-C., Perryman R., Valdes-Cruz L., Scholl F.

$\mathrm{RV}$ morphology remains a risk factor for early postoperative outcome after Fontan operation Nordmeyer S., Rohder M., Miera O., Peters B., Berger F., Ovrutskiy S.

Levosimendan versus Milrinone after Corrective Open-Heart Surgery in Neonates and Infants

Lechner E., Hofer A., Leitner-Peneder G., Freynschlag R., Mair R., Weinzettel R., Rehak P., Gombotz H.

\section{Nurses role}

Chair: Sonia Lopez (Madrid, ES), Maria del Carmen Rodriguez (Madrid, ES)

Health education for parents of children suffering from CHD. Nursing support during and after hospitalization

Ana Clara Félix

Long term complications and prognosis in patients after TGA surgery

Maria del Mar Calvo

Nursing consultation, a central focus on care to children undergoing heart transplantation and their families, in postransplant period

Ana Ines Costa

Heart failure in children

Hans Coolen

Round table discussion

AEPC Business Meeting

FRIDAY, MAY 20, 2011

WG Business Meeting: Preventive care

WG Business Meeting: Interventional Cardiology

WG Business Meeting: Psycho-Social care from fetus to adult 
08:00-09:00

Andalucia III room

08:00-09:00

Press room

08:00-09:00

Seminar 8

09:00-10:30

Manuel de Falla

09:00

09:15

09:30

09:45

10:00

10:30-11:30

Exhibition Hall 1

10:30-11:30

Exhibition Hall 1

10:30

PW3-1

10:35

PW3-2

10:40

PW3-3

10:45

PW3-4

10:50

PW3-5

10:55

PW3-6

11:00

PW3-7

11:05

PW3-8

11:10

PW3-9

$11: 15$

PW3-10

11:20

PW3-11

11:25

PW3-12
WG Business Meeting: GUCH Task Force

WG Business Meeting: Genetics and Basic Science

WG Business Meeting: Congenital Heart Surgery

JSPSCC/AEPC session: Complex LVOTO

Chair: William J Brawn (Birmingham, UK), Felix Berger (Berlin, DE)

Echocardiography: role, limitations and pitfalls

Jan Marek

CMR/CT: how can it help the surgeon plan an operation?

Satoshi Yasukochi

The half-turn technique for TGA with VSD and PS

Masaaki Yamagishi

The Ross-Konno/Nikaidoh

Viktor Hraska

Round table discussion

Coffee Break, Exhibition

\section{Poster Walk 3}

Correlation of maternal flecainide levels and therapeutic effect in fetal supraventricular tachycardia Vigneswaran T., Callaghan N., Andrews R., Miller O., Rosenthal E., Sharland G., Simpson J. Chronic cardiac pacing induces structural and functionnal remodeling in the porcine postnatal developing heart

Zemmoura A., Bordachar P., Dos Santos P., Barandon L., Calderon J., Lemoine S., Ritter P., Ploux S., Haissaguerre M., Thambo J.B.

The lumenless 4.1 Fr transvenous Pacemaker electrode (Medtronic 3830) in patients with congenital heart defects - a single center experience with 39 patients

Peters B., Miera O., Ewert P., Ovrutskiy S., Nagdyman N., Berger F.

Unravelling The Mechanisms Behind The Hemodynamic And Autonomic Remodeling

Induced By Orthostatic Training

Laranjo S., Oliveira M., Tavares C., Geraldes V., Santos S., Pinto F.F., Ferreira R.C., Rocha I.

Pregnancy and neonatal complications in women with congenital cardiac disease - a longterm follow-up study

Wacker-Gussmann A., Thriemer M., Yigitbasi M., Berger F., Nagdyman N.

Impaired whole blood coagulation and plateled function in patients with cyanotic congenital heart disease

Mebus S., Braun S., Eicken A., Hager A., Hess J., Kaemmerer H.

Long-term neo-aortic growth in arterial switch operation versus Ross procedure. Is there a difference?

Kaldararova M., Kantorova A., Hraska V., Nosal M., Masura J., Vrsanska V.

Long term follow up of adolescent and adult grown up congenital heart disease (GUCH) patients after modified Fontan operation

Ovrutskiy S., Miera O., Peters B., Nagdyman N., Ewert P., Hübler M.,

Alexi-Meskishvili V., Hetzer R., Berger F.

Intellectual outcome in children after complex cardiac surgery: Arterial switch operation vs.

total cavopulmonary connection

Vahsen N., Toussaint-Goetz N., Asfour B., Schneider M.

Induction therapy with Daclizumab in pediatric heart transplantation

Fuchs A.T., Birnbaum J., Greil S., Egermann N., Kozlik-Feldmann R., Netz H.

Results of pediatric heart transplantation after 15 and 20 years: How are they now?

Behnke-Hall K., Bauer J., Thul J., Logeswaran T., Akintuerk H., Valeske K., Schranz D.

Spanish Collaborative Group in Pediatric Ventricular Assisted Device: Experience with the Berlin Heart Excor

Medrano C., Albert D., Tejero M.A., Marcos-Alonso S., Labrandero C., Brochet G., Goncalves A., Casares J., Portela F., Polo L., Sánchez-Galindo A.C., Balcells J., Frís M., Ferrer A., Menendez J.J. 
10:30-11:30

\section{Exhibition Hall 1}

10:30

PW4-1

10:35

PW4-2

10:40

PW4-3

10:45

PW4-4

10:50

PW4-5

10:55

PW4-6

11:00

PW4-7

11:05

PW4-8

11:10

PW4-9

11:15

PW4-10

11:20

PW4-11

11:25

PW4-12

11:30-13:00

Manuel de Falla

11:30

11:45

12:00

12:15

$12: 30$

\section{Poster Walk 4}

Fetal Congenital Heart Disease in Twins with fully identified Zygosity: genetic or epigenetic?That is the question perhaps answered by an international multicenter study of 144 monozygotic twins

Joinau F., Guimiot F., Areias J.C., Sharland G., Marantz P., Vaskmann G., Zeilinsky P., Schleich J.M., Hyett J., Heitz F., Godart F., Lopes L., Fraisse A., Luton D., De Geeter B., Pangaud N., Vayssiere C., Vuillard E., Norouzi K., Azancot A.

Heart valve tissue-engineered matrices attenuate monocyte binding and procoagulant responses in human endothelial cell cultures exposed to S. aureus, S. sanguis and S. epidermidis

Heying R., Eyskens B., Cools B., Wolf C., Beekhuizen H., Jockenhoevel S., Hoylaerts M.F., Schmidt K.G., Schroten H.

Inhibition of calcineurin-signalling attenuates RV adaptation to pressure

load in mice

Bartelds B., Borgdorff M.A.J., Boersma B., Takens J., Smit-van-Oosten A.,

De Windt L.J., Berger R.M.F.

Long term changes in retinal vasculature from Kawasaki Syndrome and its potential role in coronary risk stratification

Lim C.W.T., Pang A., He X.P., Quek S.C., Leo S.W., Wong T.Y.

Quality of life in asymptomatic children and adolescents before and after diagnosis of hypertrophic cardiomyopathy through family screening

Bratt E.-L., Berntsson L., Axelsson A.B., Östman-Smith I.

Echocardiographic and Biochemical Findings of type 1 diabetic children and adolescents:

Cardiovascular risk in diabetic children

Levent E., Kar S., Goksen D., Darcan S., Ozyurek A.R.

First 20 years of paediatric heart transplantation in Sweden: Comprehensive outcome after listing for transplantation and

post-transplant results 1989-2009

Higgins T., Bennhagen R., Waihlander H., Gilljam T.

Cardiac anomalies in Noonan sydrome: experience in 64 patients

Banaudi E., Riggi C., Baldassarre G. *, Ferrero G.B. *, Silengo M.*, Agnoletti G.

Central and Peripherial Systolic Blood Pressure in Healthy Children and Adolescents and in Patients with Juvenile Hypertension

Hidvégi $E$., Illyés $M$.

International Trial of Promising New Auditory Training Program for Distinguishing Innocent and Pathological Murmurs

Finley J., Nicol P., Caissie R., Newman A., Hoyt B., MacAulay D., Wright H., Yim D.

Long term outcome of coronary artery lesions after Kawasaki Disease in children

Di Filippo S., Lega C., Ducreux C., Sassolas F., Gouton M., Bakloul M., Veyrier M., Bozio A.

Malignancy after pediatric heart transplantation: a multi-institutional study

Marcos-Alonso S., Arizón J.M., Garcí-Guereta L., Segovia J., Roig E., Almenar L.,

Rábago G., Delgado J., González-Vilchez F., Camino M., Albert D., Lage E.,

Pérez-Villa F., Pascual D., Manito N., Blasco T.,

Muñiz J., Crespo-Leiro M.

\section{The role of imaging before, during and after intervention}

Chair: Grazyna Brzezinska-Rajszys (Warsaw, PL), John Simpson

(London, UK)

What the imager can do to help

Tara Bharucha

What the interventionist needs to know

Peter Ewert

ICE versus TOE

Neil Wilson

CMRI guided interventions - Are we there yet?

Reza Razavi

Round table discussion 
11:30-13:00

Andalucia III room

11:30

09-1

$11: 42$

09-2

$11: 54$

09-3

12:06

09-4

$12: 18$

09-5

12:30

09-6

$12: 42$

O9-7

11:30-13:00

Andalucia I+ II room

11:30

06-1

11:44

06-2

11:58

06-3

$12: 12$

O6-4

$12: 26$

06-5

$12: 40$

06-6

13:00-14:30

Exhibition Hall 2

14:30-16:00

Manuel de Falla

$14: 30$
Abstract Session 9 General Cardiology 1

Chair: Sylvia Di Filippo (Lyon, FR), Federico Gutierrez-Larraya (Madrid, ES)

Clinical Characteristics of Pediatric Pulmonary Hypertension: Results from the global registry Tracking Outcomes and Practice in Pediatric Pulmonary Hypertension (TOPP) Berger R.M.F., Humpl T., Schulze-Neick I., Raskob G., Ivy D.D., Jing Z.-C.,

Bonnet D., Beghetti M., Barst R.J.

Exercise capacity in children with isolated congenital complete atrioventricular block: does pacing make a difference?

Blank A.C., Hakim S., Strengers J.L., Tanke R.B., van Veen T.A.B., Vos M.A., Takken T.

The efficacy and safety of new strategy for refractory Kawasaki disease

Ishii M., Ogata S., Honda T., Ogihatra Y.

The outcomes of the extracardiac conduit Fontan operation in patients with heterotaxy syndrome: Experience in a single institute

Ko H.K., Ko J.K.

Mild residual pulmonary stenosis after correction of Tetralogy of Fallot is associated with a reduced risk of pulmonary valve replacement during follow-up

Hylkema M.G., van der Hulst A.E., Vliegen H.W., Hazekamp M.G., Bax J.J., Rijlaarsdam

M.E.B., Holman E.R., Blom N.A., Roest A.A.W.

Outcome of acute myocarditis: a single-center 8-year experience

Asakai H., Hama T., Kaneko M., Misaki Y., Kaneko Y., Nakagawa S., Kato H.

Echocardiographic Findings in 30 Children with Various Lysosomal Storage Disease

Weber R., Rohrbach M., Baumgartner M., Valsangiacomo Buechel E.R., Kretschmar O., Attenhofer Jost C.H.

\section{Young Investigator Award}

Jury's Chair: Maurice Beghetti (Geneva, $\mathrm{CH}$ )

Judges: Toshio Nakanishi (Tokyo, JP), Ina Michel-Behnke (Viena, AT),

Kisaburo Sakamoto (Shizuoka, JP)

4-dimensional flow patterns in the ascending aorta differ strongly between bicuspid and tricuspid aortic valves

Schneider E.P., Lyko C., Meierhofer C., Stern H., Markl M., Hutter A., Hager A., Martinoff St., Hess J., Fratz S.

The cardio renal anemia syndrome in adult patients with congenital heart disease

Shimada E., Inai K., Shinohara T., Yamamura H., Nakanishi T.

Distinct patterns of functional right ventricular adaptation to experimental right ventricular pressure vs volume overload

Borgdorff M.A.J., Bartelds B., Smit- van Oosten A., Steendijk P., de Vroomen M., Berger R.M.F. MicroRNAs may control mRNAs in circulating peripheral blood mononuclear cells during the acute phase of Kawasaki disease

Saito K., Takasaki I., Hirono K., Ibuki K., Watanabe K., Bowles N.E., Ichida F., Miyawaki T.

Clinical application of a vagal hyperreactive animal model

Helms P., Livolsi A., Niederhoffer N., Dali-Youcef N., Rambaud C., Olexa C.,

Mokni W., Gies J.P., Bousquet P.

Exploring a novel molecular mechanism underlying the cardiac development implicated in the outflow tract defects

Kodo K., Uchida K., Tsuchihashi T., Nakanishi T., Matsuoka R., Yamagishi H.

\section{Lunch}

\section{D-TGA: Arterial switch controversies}

Chair: Shakeel Qureshi (London, UK), Juan Comas (Madrid, ES)

Prostaglandin management. Rashkind management. Timing.

Late presentation. Is preoperative catheteritation necessary?

Late pulmonary stenosis management. Ao regurgitation.

Postoperative coronary evaluation

The cardiologist's approach

Joseph deGiovanni 


\begin{tabular}{|c|c|}
\hline 14:45 & $\begin{array}{l}\text { The surgeon's approach } \\
\text { George Sarris }\end{array}$ \\
\hline \multirow[t]{2}{*}{ 15:00 } & Surgery experts: \\
\hline & $\begin{array}{l}\text { Viktor Hraska (DE), Francisco Portela (SP), Kisaburo Sakamoto (JP), } \\
\text { Christian Schriber (GE) }\end{array}$ \\
\hline \multirow[t]{2}{*}{ 15:20 } & Cardiology Experts \\
\hline & $\begin{array}{l}\text { Younes Boudjemline (FR), Konrad Brockmeier (DE), Eero Jokinen (FI), } \\
\text { Marteen Witsenburg (NL) }\end{array}$ \\
\hline $15: 40$ & Round table discussion \\
\hline $\begin{array}{l}\text { 14:30-16:00 } \\
\text { Andalucia I+II room }\end{array}$ & $\begin{array}{l}\text { Abstract Session } 8 \text { Dysrythmias } \\
\text { Chair: Juha-Matti Happonen (Helsinki, FI), Alpay Celiker (Istanbul, TR) }\end{array}$ \\
\hline 14:30 & Development of the sinoatrial and atrioventricular nodes in the avian embryo: a reference \\
\hline O8-1 & $\begin{array}{l}\text { series of morphological and electrophysiological changes during maturation } \\
\text { Vicente-Steijn R., Kolditz D.P., de Vries A.A.F, Schalij M.J., Poelmann R.E., Gittenberger-de } \\
\text { Groot A.C., Jongbloed M.R.M }\end{array}$ \\
\hline $14: 42$ & Pathologic anatomy of the coronary sinus and cardiac veins in double discordance \\
\hline 08-2 & $\begin{array}{l}\text { (congenitally corrected transposition of the great arteries) } \\
\text { Houyel L., Belli E., Serraf A. }\end{array}$ \\
\hline $14: 54$ & Permanent Cardiac Pacing in Children-Choosing the Optimal Pacing Site: \\
\hline 08-3 & $\begin{array}{l}\text { A Multi-Center Study } \\
\text { Janousek J., van Geldorp I.E., Krupickova S., Rosenthal E., Tomaske M., Früh M., Elders J., } \\
\text { Hiippala A., Gebauer R.A., Kubus P., Gabbarini F., } \\
\text { Clur S.-A., Nagel B., Ganame J., Papagiannis J., Marek J., Nürnberg J.-H., Wren C., } \\
\text { Friedberg M., de Guillebon M., Tisma-Dupanovic S., Prinzen F., Delhaas T. }\end{array}$ \\
\hline 15:06 & Cardiac Resynchronization Therapy in Pediatric and Congenital Heart Disease Patients: \\
\hline O8-4 & $\begin{array}{l}\text { A Long-Term Single Center Experience } \\
\text { Rotstein A., Davis A.M., Kamberi S., Scicluna D., Koleff J., Cheung M., } \\
\text { Weintraub R.G., Pflaumer A. }\end{array}$ \\
\hline 15:18 & Acute and Long-Term Outcome after Catheter Ablation of Supraventricular Tachycardia in \\
\hline O8-5 & $\begin{array}{l}\text { Patients after the Mustard or Senning Operation for D-Transposition of the Great Arteries } \\
\text { Hessling G., Wu J., Ammar S, Reents T., Fichtner S., Zhu P., Estner H., Jilek C., Hess J., } \\
\text { Deisenhofer I. }\end{array}$ \\
\hline 15:30 & Genetic background of long QT syndrome in infants, children, and adolescents in Japan \\
\hline 08-6 & Yoshinaga M., Kucho Y., Watanabe A., Ikegami K., Kojo K., Tanaka Y. \\
\hline 15:42 & Predictors of Adverse Events in Children with Arrhythmogenic Right Ventricular \\
\hline \multirow[t]{2}{*}{ O8-7 } & Cardiomyopathy \\
\hline & Farhan M., Hamilton R.M. \\
\hline & Monitoring in the ICU \\
\hline Andalucia III room & Chair: Eduardo da Cruz (Denver, USA), Evelyn Lechner (Linz, AT) \\
\hline
\end{tabular}

News about monitoring the cardiac patient in the ICU

14:30-16:00

Press room

16:00-16:30 Exhibition Hall 1
Invasive hemodynamic monitoring: why, how and what to measure Nikolaus Haas

Non-invasive hemodynamic monitoring: methods and their reasonable application Joris Lemson

\section{News on sedating the cardiac patient in the ICU}

Dexmedetomidine in Cardiac Critical Care. Current perspective: Lessons learn from the past and current practice

Ricardo Muñoz

Round table discussion

\section{Anatomic exhibition 2: "Left and right ventricular outflow tract diseases"}

Chair: Annalisa Angelini (Padua, IT)

Adriana Gittenberger de Groot

Jose Luis Zunzunegui

\section{Coffee Break, Posters and Exhibition}


16:30-18:00

Manuel de Falla

16:30

$16: 45$

17:00

$17: 15$

$17: 30$

16:30-18:00

Andalucia I+II room

16:30

$16: 45$

17:00

$17: 15$

$17: 30$

16:30-18:00

Andalucia III room

16:30

07-1

16:42

07-2

16:54

07-3

17:06

O7-4

$17: 18$

07-5

17:30

07-6

$17: 42$

07-7

18:00-20:00

Manuel de Falla

09:00-10:30

Manuel de Falla
TGA: long-term follow-up in atrial switch

Chair: Andre Bozio (Lyon, FR), András Szatmàri (Budapest, HU)

Long-term follow-up of Mustard/Senning

Koichiro Kniwa

Arrhythmias in the Mustard/Senning population

Judith Bouchardy

Catheter Interventions in the Mustard/Senning

Ingo Daehnert

Late arterial Switch after retraining LV

Nicole Sekarski

Round table discussion

Psychosocial WG session: "quality of care"

Chair: Ulrike Bauer (Berlin, DE), Giacomo Pongiglione (Roma, IT)

Expectations of care and suggested strategies to deal with inequalities in health care throughout Europe-the view of the parent support organisations

Hermine Nock

The challenge of combining large centre surgical care with more locally accessible medical and psychosocial care

Frank Casey

How do achieve the best, behavioural, educational and employment outcomes for the

Adolescent with $\mathrm{CHD}$

Jo Wray

Indicators of Quality

Bohdan Maruszewski

Round table discussion

\section{Abstract Session 7 Imaging}

Chair: Giovanni di Salvo (Naples, IT), Sylvie de Filippo (Lyon, FR)

Four-dimensional velocity encoded magnetic resonance imaging improves blood flow quantification in congenital heart disease

Nordmeyer S., Riesenkampff E., Kropf S., Berger F., Kuehne T.

Effect of age on exercise capacity and cardiac reserve in patients with pulmonary atresia with intact ventricular septum after biventricular repair

Romeih.S, Groenink M., Roest A.A.W., van der Plas M.N., Hazekamp M.G.,Spijkerboer A.M., Mulder B.J.M., Blom N.A.

Quantitative blood flow analysis of aorto-pulmonary collaterals by 3D-flow

Phase-Contrast Magnetic Resonance Imaging in patients with single ventricle physiology

Valverde I., Nordmeyer S., Crelier G., Kuehne T., Beerbaum P.

Computer aided planning of patches and conduits for surgery in congenital

heart disease

Riesenkampff E., Hübler M., Rietdorf U.,Heimann T., Schwarz T., Meinzer H.-P., Berger F,

Kuehne $T$.

Speckle tracking in hypoplastic left heart syndrome: correlation with magnetic resonance imaging and the impact of ventricular morphology

Bellsham-Revell H., Bell A.J., Miller O., Greil G., Simpson J.M.

Mechanisms of Tricuspid Valve Regurgitation in Hypoplastic Left Heart Syndrome: A Case-

Matched Study

Bharucha T., Atlin C., Seller N., Honjo O., Caldarone C.A., van Arsdell G., Mertens L.

Cardiac involvement in Duchenne Muscular Dystrophy (DMD) - a detailed cardiac magnetic resonance imaging study in 39 patients

Greim V., Schmid A., Joerges A., Boettler P., Burkhardt B., Trollmann R., Schröder R., Dittrich S.

\section{SECPCC Business Meeting}

SATURDAY, MAY 21, 2011

\section{PA/VSD/MAPCAS}

Chair: Caroline Ovaert (Brussels, BE), Christian Schreiber (Munich, DE) 
09:00

09:15

09:30

09:45

10:00

09:00-10:30

Andalucia I+ II room

09:00-10:30

Andalucia III room

09:00

010-1

09:12

010-2

09:24

010-3

09:36

010-4

09:48

010-5

10:00

010-6

10:12

010-7

10:30-11:00

Exhibition Hall 1

11:00-12:30

Andalucia I+II room

$11: 00$

$11: 15$

$11: 30$

$11: 45$

$12: 00$
What imaging modalities offer for optimal management

Titus Kuehne

Repair or palliation: timing, order of play, staged or complete

William J Brawn

Catheter intervention (balloons, cutting balloons, stents)

Marc Gewillig

Outcome, late problems and expectations

Andreas Eicken

Round table discussion

\section{Puzzle the Experts}

Chair: Gurleen Sharland, (London, UK), Queralt Ferrer (Barcelona, ES)

Experts: Jose Carlos Areias (PT), Joaquín Bartrons (ES), Klaus Schmidt (DE),

Vita Zidere (UK)

\section{Abstract Session 10 End stage heart and lung disease}

Chair: Maurice Beghetti (Geneva, CH), Michael Burch (London UK)

Enlarging the genetic spectrum of cardiomyopathies. Preliminary results of the MyEstela

Pediatric Cohort Study

Medrano-López C., Vázquez-Álvarez M.C., Camino-López M., Blanco-Soto P., CentenoJiménez M., Monserrat-Iglesias L., Orera-Clemente M., Maroto-Álvaro E., The MyEstela Study Group

Diagnostic Evaluation in Pediatric Pulmonary Hypertension $(\mathrm{PH})$ - Results from the First Pediatric Global Registry: Tracking Outcomes and Practice in Pediatric Pulmonary Hypertension (TOPP)

Beghetti M., Berger R.M.F., Schulze-Neick l., Raskob G., Day R., Pulido T., Feinstein J., Barst R.J., Humpl T.

Does reversed apical or basal left ventricular rotation recover following medical therapy in children with dilated cardiomyopathy?

A two-dimensional speckle tracking imaging study

Udink ten Cate F.E.A., Lorenz S.R.W., Khalil M., Schmidt B.E., Brockmeier K., Sreeram N.

Clinical characteristics and outcome of heart transplant in adults with Congenital Heart

Diseases. Subanalysis of Spanish Registry on Heart Transplantation

Albert D.C., Paniagua M.J., Almenar L., Brossa V., Crespo M.G., Segovia J., Palomo J., Delgado J., González-Vilchez F., Manito N., Lage E., Garclá-Guereta L., Rodríguez-Lambert J.L. Recurrent Post-transplant lymphoproliferative disorder in paediatric heart transplant recipients

Logeswaran T., Behnke-Hall K., Rueblinger L., Bauer J., Thul J., Schranz D.

Survival adjusted with age is similar in adults with Eisenmenger syndrome and other types of pulmonary artery hypertension

Bonello B., Renard S., Hubert S., Mancini J., Habib G., Fraisse A.

The impact of cardiac resynchronization therapy on outcome of infants with severe congestive heart failure due to dilated cardiomyopathy - the importance of detecting "optimal pacing site" in OR

Yasukochi S., Takigiku K, Maatsui H, Inoue N, Watanabe S, Mori H, Morimoto Y

\section{Coffee Break, Posters and Exhibition}

\section{Device session}

Chair: Juha-Matti Happonen (Helsinki, Fl), Fabrizio Drago (Roma, IT)

Pacemaker therapy in congenital AVB

Alpay Celikey

Dyssynchronous heart failure-a device needed and helpful?

Jan Janousek

Selecting the appropriate pacing site in pediatric patients

Tammo Delhaas

Pediatric ICD therapy: indications and clinical outcome

Thomas Kriebel

Round table discussion 
11:00-12:30

Manuel de Falla

11:00-12:30

Andalucia III room

11:00

011-1

$11: 12$

011-2

11:24

011-3

11:36

011-4

11:48

011-5

12:00

011-6

12:12

011-7

12:30-13:30

Manuel de Falla

$12: 30$

08:00-18:00

Exhibition Hall 1

$\mathrm{P}-1$

P-2

P-3

P-4

P-5

P-6

P-7

P-8
Interventions: Failures and Successes

Chair: Shakeel Qureshi (London, UK), Caroline Ovaert (Brussels, BE)

\section{Abstract Session 11 General Cardiology 2 \\ Chair: Daniel de Wolf (Gent, BE), Enrico Chiappa (Florence, IT)}

Prior administration of urinastatin decrease the total dosage

of gamma-globulin in early stage Kawasaki disease

Yoshikane Y., Hashimoto J., Ueda M., Ogawa A., Hirose S.

Effect of dispensing with antibiotic prophylaxis before dental treatment in patients with congenital heart disease: Analysis of 21 consecutive cases of infective endocarditis after the introduction of NICE guidelines in April 2008

Wong J.K.B., Witter T., Rosenthal E.

Univentricular Hearts in Denmark 1977-2009: Incidence and Survival

Idorn L., Jensen A.S, Juul K., Reimers J.I., Søndergaard L.

Pulse oximetry home monitoring in infants with single ventricle physiology and a surgical shunt as the only source of pulmonary blood flow

Öhman A., Nilsson B., Strömvall-Larsson E., Cavigelli-Brunner A., Mellander M.

Evaluation of the aortic morphology and function in adolescents after coarctation (CoA) repair using MRI: New details of a systemic vessels disesase

Eichhorn J.G., Kropp F., Ley S., Fischer M., Loukanov S., Sebening C., Gorenflo M.

Evaluation of aortic morphology and elastic properties in children and adolescents with

Ullrich-Turner syndrome (UTS): High prevalence of aortic changes already in early life

Eichhorn J.G., Kneppo C., Ley S., Knauer-Fischer S., Inta I.M., Gorenflo M., Bettendorf M.

Acute Neonatal Hypertensive Crisis With Circulatory Failure: Be Aware Of The Wolf In Disguise

Louw J.J., Thewissen L., Smits A., Eyskens B., Heying R., Cools B., Levtchenko E.,

Allegaert K., Gewillig M.

\section{Closing session}

Chair: Ramón Bermudez-Cañete (Madrid, ES), Shakeel Qureshi (London, UK)

Integration of multi-imaging information in the interventional suite: a key to advanced structural heart disease interventions

Carlos Ruiz

\section{WEDNESDAY, MAY 18, TO SATURDAY, MAY 21, 2011}

\section{Posters}

\section{Arrhythmia/electrophysiology}

Effect of right bundle branch block on T peak to end interval

Benatar A., Dewals W., Decraene T., Feenstra A.

Home Monitoring in children and young patients with a congenital heart disease and

electronic devices

Zartner P.A., Toussaint-Goetz N., Wiebe W., Schneider M.B.E.

Long-term Fate of Patients With Congenital Heart Disease Undergoing Cardiac

Resynchronization Therapy

Janousek J., Krupickova S., Gebauer R.A., Kubus P.

18 Years of Paediatric Catheter Ablation in One Country: Long-Term Results

Janoušek J., Vit P., Zaoral L., Peichl P., Gebauer R.A., Fiala M., Kubuš P.

Permanent Epicardial Pacing in Children: Long-Term Results and Factors Modifying

Outcome

Janousek J., Kubuš P., Materna O., Gebauer R.A., Matějka T., Gebauer R., Tláskal T.

Assessment of electrical and mechanical heart function in children after atrioventricular node slow pathway ablation

Sileikiene R., Vaskelyte J., Sileikyte V., Baksiene D.

Selective-site pacing in children using the SelectSecure System: effect on left ventricular function

Gabbarini F., Corleto A., Agnoletti G.

A frequent anomalous morphological pattern of the coronary sinus in corrected transposition of the great arteries: Implications for cardiac resynchronization therapy

Aiello V.D., Ferreira F.C.N., Scanavacca M.I., d'Avila A. 
P-9

$\mathrm{P}-10$

$\mathrm{P}-11$

$\mathrm{P}-12$

$\mathrm{P}-13$

$\mathrm{P}-14$

$\mathrm{P}-16$

$\mathrm{P}-17$

P-19

P-20

$\mathrm{P}-21$

$\mathrm{P}-22$

$\mathrm{P}-23$

P-24

P-25

P-26

$\mathrm{P}-27$
Electrocardiographic screening of one-month-old infants for long QT syndrome in Japan

Yoshinaga M., Ushinohama H., Sato S., Tauchi N., Horigome H., Kojo K., Tanaka Y., Takahashi H., Shimizu W., Sumitomo N., Nomura Y., Takahashi K, Nagashima M. Isosorbide Dinitrate Is a Safe Provocative Agent In Head up Tilt Test in Children and Adolescents

Sabri M.R., Maghzian M.

Fifteen year experience with accessory pathway ablation in children and young adults with congenital heart disease by a single pediatric electrophysiology team

Avramidis D., Alexopoulos C., Kirvassilis G., Tzifa A, Bonou P., Papagiannis J.

Sotalol in Foetal Atrial Tachyarrhythmias. A Retrospective Analysis

Freund M.W., van der Heijden L.B., ter Heide H., Freund J.E., v Iperen G., Manten W., Pistorius L., Oudijk M.

Outcomes of Radiofrequency Ablation and Cryoablation in Children and Adolescents

Mangat J., Ladusans E., Narayanan A., Fitzpatrick A., Hall M., Todd D.

Identification of electrophysiological substrate in patients with repaired tetralogy

of Fallot

de Guillebon M., Sacher F., Derval N., Bordachar P., Iriart X., Haissaguerre M., Thambo J.B. Heart rate variability in young patients with hypertrophic cardiomyopathy is a useful indicator of risk for complex ventricular arrhythmias

Östman-Smith I., Arnell M., Allahyari P., Smith N.

Cardiac resynchronization therapy in children-experience of the Hungarian Paediatric

Heart Centre

Szepesvary E., Környei L., Kassai I., Szatmari A.

One cryolesion is often enough to treat children with septal arrhythmia substrates in the

right atrium

Hiippala A., Happonen J.M.

Late recovery of surgical atrio-ventricular block is not exceptional

Vugts G., van Geldorp I.E., Vanagt W.Y., Meyns B., Willems R., Rega F., Gewillig M., Delhaas $T$.

Low incidence of inappropriate shock in children with implantable cardioverter defibrillator. A single-institution experience

Maltret A., Villain E., Tamisier D., Jauvert G., Horvilleur J., Lacotte J., Bonnet D.

Contact Force Controlled Zero-Fluoroscopy Catheter Ablation of

Right-Sided and Left-Atrial Arrhythmias

Kerst G., Weig H.-J., Weretka S., Seizer P., Gawaz M., Hofbeck M., Schreieck J.

Congenital Junctional Ectopic Tachycardia - difficult clinical problem

Bieganowska K., Miszczak-Knecht M., Brzezinska-Paszke M., Posadowska M., Rękawek J., Kaszuba A., Pregowska K., Szumowski $t$.

Safety and efficacy of simplified femoral approach with Gold Tip Electrodes for RFCA on paroxysmal SVTs in children

Ras M., Stec S., Sledz J., Szydlowski L., Klank-Szafran M., Mazij M., Ludwik B., Dudek K., Futyma M., Spikowski J., Kulakowski P.

Catheterablation of accessory pathways in children and adolescents: results in

167 consecutive patients

Környei L., Szil-Török T., Földesi Cs., Kardos A.,Szatmári A.

Population-based long term outcome of pediatric catheter ablation of common supraventricular tachycardias in patients without structural heart disease

Hiippala A., Happonen J.M.

The funny current channel HCN4 delineates the developing cardiac conduction system in the chicken heart

Vicente-Steijn R., Passier R., Wisse L.J., Schalij M.J., Poelmann R.E., Gittenberger-de

Groot A.C., Jongbloed M.R.M.

Progression to first degree heart block in preschool children fetally exposed to Ro52 autoantibodies

Eliasson H., Bergman G., Mohlkert LA., Wahren-Herlenius M.,

Sonesson SE.

Analysis of QT dispersion and corrected QT interval in children with hypertrophic

cardiomyopathy

Bobkowski W., Krauze T., Piskorski J., Baszko A., Surmacz R., Moszura T.,

Siwińska A., Guzik P. 
$\mathrm{P}-28$

P-30

$\mathrm{P}-31$

P-36

Analysis of the signal-averaged QRS complex width in healthy children and in children with hypertrophic cardiomyopathy Bobkowski W., Surmacz R., Krauze T., Piskorski J., Baszko A., Moszura T., Jaremba O., Siwińska A., Guzik $P$

Vectorcardiographic measurements of QT interval in a paediatric LQTS population

Diamant U.B., Winbo A., Jensen S.M., Rydberg A.

First Results from the Austrian LQTS Registry

Haselwanter E., Gamillscheg A., Stein J., Tulzer G., Emhofer J.,

Marx M., Wolf C., Fritz M., Kimmersdorfer S., Perneczky E., Ehringer D.,

Salzer-Muhar U.

Tilt-table and ergometry tests in relation to cardiac status

Kadic A., Dinarevic S, Begic Z., Hadžic A.

\section{Basic science}

Changes of Gene Expressions in Monocrotaline induced Pulmonary Hypertension Rats after Bone Marrow Cell Transfusion

Hong Y.M., Kim S.J., Kim K.C., Cho M.S., Kim H.S., Sohn S.J.

Apoptosis associated Gene Expressions of in Monocrotaline-Induced Pulmonary

Hypertension in Rats after Bosentan Treatment

Jung J.Y., Kim K.C., Hong Y.M.

Rapidly activating delayed rectifier $\mathrm{K}+$ current during post-natal development in mouse ventricle

Hoshino S., Nakagawa M., Takeuchi Y., Omatsu-Kanbe M., Matsuura H.

Postnatal developmental changes in the TRPC channels in mouse cardiomyocytes

Hoshino S., Nakagawa M., Takeuchi Y., Omatsu-Kanbe M., Matsuura H.

Right ventricle function analysis by using RV papillary muscle

Urashima T., Kusakari Y., Itohisa M., Kawachi S., Saito R., Fujiwara M., Ogawa K., Ida H., Nakazawa M., Eto $Y$.

Infective endocarditis in patient with congenital heart disease and without vegetations

Cobos Carrascosa E., Ortega Montes A., Sánchez Forte M.,

Rodriguez Lucenilla M.I., Giménez Sánchez F., Salvador Sáncehz J.

Factors influencing on formation of heart rhythm disturbances in newborns

Kovalev I.A., Svintsova L.I., Usenkov S.Yu.

RFA of tachyarrhythmias in children of one year old

Svintsova L.I., Kovalev I.A., Popov S.V., Murzina O.Yu.

Properties of heart remodeling in children with congenital heart diseases complicated by pulmonary hypertension

Yanulevich O.S., Kovalev I.A., Sokolov A.A., Krivoshchekov E.V.

Comparative assessment of intracardiac hemodynamics state in children with ventricular premature beats from RVOT and LVOT

Chernyshov A.A., Kovalev I.A., Zavadovsky K.V., Popov S.V.

Cardiotrophin-1 is differentially induced in the myocardium of infants with congenital cardiac defects depending on hypoxemia

Heying R., Qing M., Wöltje M., Schumacher K., Sokalska M.,

Vazquez-Jimenez J., Seghaye M.-C.

Coronary ostia patterning in conotruncal defects

Bajolle F., Houyel L., Laux D., Bonnet D.

Genetic polymorphism of methylenetetrahydrofolate reductase as a risk factor for

congenital heart defect in Romanian children

Togănel R., Bănescu C., Muntean I., Făgărășan A., Duicu C., Gozar L.

Interaction of Fetal Cardiology and Molecular Biology : About three cases of GATA4 deletion in fetuses with conotruncal malformations

Guimiot F., Aboura A., Delezoide A.-L., Chitrit Y., Azancot A.

Apolipoprotein e2 allele - a genetic risk factor for nocturnal blood pressure elevations in Type 1 diabetes

Pavlovic M., Holl R.W., Venetz P., Gallati S., Schaller A.

Coronary Flow and Reactivity, but not Arrhythmia Vulnerability, Are Affected by Cardioplegia During Cardiopulmonary Bypass Surgery of Piglets

Liuba P., Johansson S., Pesonen E., Higgins T., Forslid A., Kornerup Hansen A.,

Perez de Sa V. 
$\mathrm{P}-48$

$\mathrm{P}-53$

$\mathrm{P}-54$

P-55

P-56

$\mathrm{P}-57$

P-58

$\mathrm{P}-59$

P-60

$\mathrm{P}-62$

P-63

P-64

$\mathrm{P}-65$

P-66

The influence of right ventricular pressure overload on the expression of pro- and antiinflammatory cytokines, growth factors and markers of apoptosis in the myocardium of newborn lambs

Liersch P., Schwarz A., Schnöring H., Hermanns-Sachweh B., Vazquez-Jimenez J., Grabitz R., Seghaye M-C

Children with atrial septal defect and significant left-to-right shunt show myocardial remodeling

Czajkowski J., Schumacher K., Wehage E., Buding B., Vázquez-Jiménez J., Seghaye M-C. A co-culture model that simulates Cardiopulmonary Bypass induced systemic inflammation: From bench to bedside Wollersheim S., Miera O., Fedarava K., Berger F., Schmitt K.R.L.

Is mild hypothermia cool enough to protect cardiac cells after hypoxia? How does propofol affect this effect?

Soltani P., Wollersheim S., Krauss A., Tong G., Berger F., Schmitt K.R.L.

Modified Blalock-Taussig-Shunts: Histopathology and Morphometry

Sigler M., Foth R., Quentin T., Ruschewski W., Kriebel T., Paul T.

Development and Characterization of Decellularized Myocardial Tissue Slices

Khalil M., Adelmann R., Köster A., Pfannkuche K., Haustein M., Hannes T., Rubach M.,

Hescheler J., Pillekamp F., Brockmeier K.

Carvajal/Naxos syndrome secondary to Desmoplakin-dominant mutation is associated with hypo/oligodontia

Bouvagnet P., Chalabreysse L., Senni F., Bruyère P., Aime B., Ollagnier C., Bozio A., Bouvagnet P.

\section{End-stage heart and lung disease}

Subcutaneous treprostinil in pediatric patients with severe pulmonary hypertension Cerro M.J., Cartón A., Deiros L., Labrandero C, Menendez J., Gomez A., Barrios M.I., Martinez M.C., Garcia M., Rubio D., Gutierrez-Larraya F.

Dilated cardiomyopathy-course and outcome in children Ablonczy L., Mózes V., Környei L., Ladányi A., Szatmári A.

Severe pulmonary hypertension mimicking pulmonary veno-occlusive disease as presenting feature of Non Ketotic Hyperglicinaemia

Menendez J.J., Cerro M.J., Dorao P., Labrandero C., Verdú C., Deiros L.,Ortega M., Cartón A., Bret M., Siles A., Fernandez A., Guereta L, Gutierrez-Larraya F, Rodriguez J.I., Lapunzina P.

Results of using of stem cells for treatment of dilated cardiomyopathy at childhood for first six patients

Bergmane I., Lacis A., Ozolins V., Lubaua I., Jakobsons E., Erglis A.

15 Year Experience in Pulmonary Hypertension Due to Congenital Heart Disease Before and After Targeted Therapies: The Durability of the Right Ventricle in this disease Apostolopoulou S.C., Kantzis M., Kourkoveli P., Rammos S.

60 patients with Eisenmenger physiology improve clinical status, hemodynamics and pulmonary endothelial function after 24 weeks of Bosentan therapy

Mebus S., Farahwaschi B., Kreuder J., Peters B., Miera O., Berger F., Lange P., Schulze-Neick I.

\section{Fetal cardiology}

Impact of intrauterine and postnatal nutritional determinants on blood pressure in early childhood

Ojala T., Aaltonen J., Laitinen K.,Poussa T., Ilmonen J., Isolauri E.

Complex Cardiac Prenatal Diagnosis: Continuing or Termination of Pregnancy? A

Retrospective Analysis

Nell S., Wijngaarde C.A., ter Heide H., Manten W., Pistorius L., Freund M.W.

The Impact of Fetal Diagnosis on Duct-Dependent Congenital Heart Lesions

Thakur V., Duthil N., Schwartz S., Jaeggi E.

Diastolic dysfunction in fetuses of Diabetic Mothers, Prenatal two dimensional and Doppler echocardiography study

Asleh N., Badarneh N.

Maternal effects of transplacental flecainide for treatment of fetal tachyarrhythmia

Vigneswaran T., Callaghan N., Andrews R., Miller O., Rosenthal E., Sharland G., Simpson J.

Performance of antenatal diagnosis to detect postnatal coarctation of the aorta

Joly H., Sassolas F., Ducreux C., Veyrier M., Bakloul M., Gouton M., Bozio A., Di Filippo S. 
P-67

P-68

P-69

P-70

P-71

P-72

P-73

P-74

P-75

P-76

P-77

P-78

P-80

P-81

$\mathrm{P}-82$

$\mathrm{P}-83$

P-84

$\mathrm{P}-85$
Prediction of biventricular versus univentricular circulation in fetal diagnosis

Svensson O., Boll A-B., Mellander $M$.

Risk for isolated ventricular septal defect in euploid fetuses with borderline or increased first trimester nuchal translucency

Zielinsky P., Naujorks A., Becker Jr E., Nicoloso L.H., Piccoli Jr A.L., Manica J.L., Pizzato P., Bender L.P., Pizzato M., Barbisan C.,

Swarowski F., Busato S., Velho L.

The fetal heart in monochorionic twin pregnancies: how much are we missing?

Goncalves E., Magalhães M., Moura C., Costa P., Brandão O., Matias A., Montenegro N., Rodrigues T., Monterroso J., Areias J.C.

Obstetric management and time to first intervention in cases of fetal congenital heart disease delivered in a tertiary centre

Jowett V., Sankaran S., Rollings S., Zahiri V., Hall R., Miller O., Simpson J.,

Kyle P., Sharland G.

Foetal dysfunction of the arterial duct: clinical spectrum and outcome

Eyskens B., Demeyer S., De Catte L., Heying R., Cools B., Brown S., Gewillig M.

Function of right ventricle in a recipient twin in twin to twin transfusion syndrome

Dangel J., Kuran J.

Pulmonary atresia with intact ventricular septum; second heart field derived developmental

clues for myocardial and coronary artery pathology

Gittenberger-de Groot A.C, Bartelings M.M., Bilardo C.M., Clur S.-A., van der Wal A.C., Mahtab E.A.F, Poelmann R.E., Jongbloed M.R.M.

Fetal Cardiomyopathy multicentre study: aethiology and clinical outcome

Ferrer Q., Arevalo S., Rueda F., Carrasco J.I., Alvarez T., Perich R., Rodríguez M.M., Albert D.C. Foetal dysrhythmias: a study in nine Spanish centres

Perin F., Briales C., Rodriguez M.M., Centeno F., Deiros L., Ferrer Q., Galindo A., Garcia de la Calzada D., Perich R.M., Rubio D., Rueda F., Teodoro S., Zabala J.I.

Prenatal diagnosis of pulmonary atresia and intact ventricular septum - can we predict rationale for prenatal intervention?

Dangel M.M., Kolesnik A., Brzezinska-Rajszys G., Dangel J.H.

A decade of antenatally diagnosed unbalanced ventricles - comparing fetal outcomes with a postnatal cohort

Michael H.C., Jones C.B., Agarwal U., Roberts D., Lim J.S.L.

Fetal supraventricular extrasystolies in a referral centre of fetal cardiology

Hamela-Olkowska A., Dangel J.H.

\section{General paediatric cardiology}

Serum adiponectin, resistin levels, insulin resistance and cardiac changes in obese and overweight children

Karakurt C., Gürbüz S., Akıncı A., Koçak G., Elkıran Ö., Nalbantoğlu Ö., Yoloğlu S.

Assessment of vascular remodelling after the Fontan procedure using a novel very high resolution ultrasound method: Arterial wall thinning and venous thickening in late follow up Sarkola T., Jaeggi E., Slorach C., Hui W., Bradley T., Redington A.

Assessment of Vascular Phenotype Using a Novel Very High Frequency Ultrasound Technique in Adolescents after Aortic Coarctation Repair and/or Stent Implantation: Relationship to Central Hemodynamics and Left Ventricular Mass

Sarkola T., Redington A., Slorach C., Hui W., Bradley T., Jaeggi E.

Serum Homocysteine, Asymmetrical Dimethylarjinine And Nitric Oxide Levels In Children With Pulmonary Arterial Hypertension

Sanli C., Oguz D., Olguntürk R., Tunaoğlu F.S., Kula S., Pașaoğlu H., Gülbahar Ö., Çevik A. Impact of Right Ventricular Volume Change on Exercise Capacity: A Comparison of Repaired Tetralogy of Fallot and Ebstein's Anomaly

Bambul Heck P., Baquet M., Schreiber Ch., Sarikouch S., Hager A., Hess J., Fratz S. NT-proBNP increase at exercise in patients with univentricular heart after total cavopulmonary connection

Hager A., Christov F., Hess J.

Pulmonary capillary haemangiomatosis: an unusual histological presentation of vascular lesion in lung biopsies from patients with congenital cardiac shunts and pulmonary hypertension

Aiello V.D., Thomaz A.M., Pozzan G., Lopes A.A.B. 
P-86

$\mathrm{P}-88$

P-90

P-91

P-92

P-94

P-95

P-96

P-97

P-98

P-99

P-100

P-101

P-102

P-103

P-104

P-105

P-106

P-107

Pre- and post-enteral feeding measurement of splanchnic/cerebral oxygenation ratio (SCOR) by near infra-red spectroscopy (NIRS) in neonates with congenital heart disease (CHD) and comparison with healthy neonates

Gaffo D., Cogo P., Passarella G., Decembrino N., Milanesi O.

Blood pressure measurement procedure at an out-patient pediatric cardiology unit Holmgren D., Swerkersson S.

Long-term Outcome of Percutaneous Transluminal Coronary Rotablator Ablation for Ischemic Heart Disease Caused by Kawasaki Disease

Suda K., lemura M., Ueno T., Nobuyoshi M., Teramachi Y., Kudo Y.,

Kato H., Matsuishi T.

Evaluation of the Cases with Silent Carditis

Pac F.A, Ballı S., Oflaz M.B., Kibar A.E., Ece I.

Pathognomonic ECG in Neonates with Enterovirus Myocarditis

Freund M.W., de Jonge N., Schroer Chr., Freund J.E., Verboon-Maciolek M.A.

Clinicopathological investigation on pediatric cardiomyopathy with special reference to ongoing myocardial damages using pathophysiological parameters

Yonesaka S., Takahashi T., Otani K., Jun S., Konno Y., Sato T., Kitagawa Y., Eto S., Ueda T., Sato A., Ichinose K., Kinjo M.

Levosimendan on severe low cardiac output in paediatric patients

Banille E., Cacciamano A, Pedernera E, Frey G, Paz G, Allub A, Peirone A, Juaneda E.

Non-invasive monitoring of microcirculation in paediatric patients suffering from septic shock

Banille E., Paz G, Cacciamano A, Ballaco M, Luján L, Resino C,

Lazzarín O, Peirone A.

Recurrent pericarditis as a sole manifestation of Familial mediterranean fever

Siurana J.M., Jimenez L., Prada F., Perez A., Palacios J.

Relationship of TNF- $\alpha-308$, IL-10-1082 Gene Polymorphisms with the Severity and

Susceptibility of Rheumatic Heart Disease

Hallioglu O., Balci S., Akbas E., Eras-Erdogan N.

Neonatal Heart Failure in Lagos University Teaching Hospital Nigeria

Daniels Q.O., Okoromah C, Omokhodion S.I.

Left ventricular systolic and diastolic function in children with overweight and obesity

Jurko Jr A., Schusterová l., Jurko A.

Impact of chest X-ray before discharge in children after cardiac surgery - prospective

evaluation

Quandt D., Knirsch W., Niesse O., Schraner T., Dave H., Kretschmar O.

Impact of acute cardiac transfers conducted by the West Midlands Neonatal Transfer

Service

Shenvi A., Harrison J., Skinner A., Dhillon A., Rasiah S.V.

Takayasu arteritis in children

De Rubens F.J., Lopez C.E., Pablos H.JL., Solórzano M.SA.

Enhanced aortic pressure wave reflection in patients after successful repair of aortic arch in children

Murakami T., Takeda A., Yamazawa H., Horibata A., Shirai T., Tateno S.,

Kawasoe Y., Niwa $K$.

Low agreement between cardiologists diagnosing left ventricular hypertrophy in children

with End Stage Renal Disease

Schoenmaker N.J., van der Lee J.H., Kuipers I.M., Ottenkamp J., van Iperen I., Frohn-Mulder

I.M.E., Tanke R.B., Groothoff J.W.

Echo Doppler Assessment of Vascular Function in Post-operative Congenital Heart Disease

Mivelaz Y., Leung M.T., Potts T.M., De Souza A.M., Potts J.E.,

Sandor G.G.S.

Fewer Electrocardiogram Abnormalities in Duchene Muscular Dystrophy Patients Treated

With Bisphosphonates

Wong K.K., Gordon K.E., Dooley J.M.

Non-compacted cardiomyopathy: clinical characteristics, evolution and prognostic data in childhood. Results of a multicentre study

Sabate A., Huertas-Quiñones V.M., Betrián P., Carretero J.M., Rissech M., Uriel S., Perich R., Collell R., Girona J., Prada F., Albert D.C.

Standard values for the 6-minute walking distance in healthy children and adolescents from different nations - which one to rely on?

Schneider J., Geiger R., Hoegler W., Rauchenzauner M., Stein J. 
P-108

P-109

P-110

P-111

P-112

P-113

P-114

P-115

P-116

P-117

P-118

P-119

P-120

P-121

P-122

P-123

P-124

P-125

P-126

P-127

Electrocardiographic Findings at Initial Diagnosis in Children with Isolated Left Ventricular Noncompaction

Dindar A., Ergul Y., Nisli K., Varkal M.A., Oner N., Dursun M., Aydogan U., Omeroglu R.E.

Left ventricular noncompaction in children and adolescents: clinical features, treatment and follow-up

Dindar A., Ergul Y., Nisli K., Varkal M.A., Oner N., Dursun M., Aydogan U., Omeroglu R.E.

Outcomes post Kawashima procedure and hepatic vein redirection for single ventricle palliation in left atrial isomerism with interrupted inferior vena cava

Vollebregt A.M., Pushparajah K., Rizvi M., Hoschtitzky A., Anderson D., Austin C., Tibby S., Simpson J.

Timing of the investigations before bidirectional cavopulmonary anastomosis

Cavigelli-Brunner A., Öhman A., Wåhlander H., Mellander M.

Noninvasive cardiac output measurement at rest and during exercise in pediatric patients following interventional or surgical ASD-closure

Wiegand G., Binder W., Kaulitz R., Riethmüller J., Hofbeck M.

Comparison of Electrocardiographic and Echocardiographic/Deformational Imaging

Screening in a Cohort of Elite High School Athletes

Johnson J.N., Lindquist R.K., Horner J.M., Ackerman M.J., Cannon B.C.,

Eidem B.W.

Whole-Blood Aggregation Test Stimulated by ADP for Evaluation of Blood Aggregation

Activity in Kawasaki Disease Patients with Anti-Platelet Management

Suzuki C., Yahata T., Hamaoka A., Fujii M., Ozawa S., Hamaoka K.

Usefulness of NT-pro-BNP in evaluation of the stage of heart failure in infants with ventricular septal defect

Skiendzielewski J., Werner B.

Diastolic function measured by Tissue Doppler Imaging in paediatric patients with End

Stage Renal Disease

Schoenmaker N.J., van der Lee J.H., Groothoff J.W., Ottenkamp J., Kuipers I.M.

Relationship between Inflammation and Oxidative Stress of Kawasaki Disease in Acute Phase

Yahata T., Suzuki C., Hamaoka A., Fujii M., Nakamura A., Ozawa S., Hamaoka K.

Evaluation of left atrial ejection force and ascending aorta elasticity in children after repair of coarctation of the aorta

Guven B., Tavli V., Mese T., Yilmazer M.M., Oner T., Demirpence S., Doksoz O, Vitrinel A.

Exercise rehabilitation for children with congenital heart disease

Plante A., Mathieu M.E., Dahdah N., Miro J., Bigras J.L., Curnier D.

Incidence of Pulmonary Artery Complications after Flo Watch Pulmonary Artery Banding

Shauq A., Lim J., Narayanan A., Gladman G., Peart I., Johnson R.A., Alphonso N.,

Venugopal P., Corno A., Ladusans E.J.

Acute Renal Failure Early After Cardiac Surgery With Extracorporeal Circulation: Long Term

Outcome?

Louw J.J., Mekahli D., Lombaerts R., Levtchenko E., Eyskens B.,

Heying R., Cools B., Gewillig M.

The Recognition of Coarctation of the Aorta in Neonates and Small Infants and Its Relation to the Course of the Disease and the Outcomes

Ligere E., Lacis A., Smits L., Ozolins V., Sikora N., Bergmane I., Lubaua I., Lace I.

Are preoperative left heart dimensions in infants with coarctation repair predictive of longterm outcome?

van der Ende J., ten Harkel A.D.J, Kuipers I.M., Rammeloo L., Blom N.A., Hazekamp M.G., Rijlaarsdam M.E.B.

Propranolol in the treatment of infantile haemangioma

Costa G., Gouveia S., Paramés F., Freitas I., Rebelo M., Martins J.D.F., Trigo C., Pinto F.F.

Predicting surgical outcome in children with acyanotic congenital heart diseases and severe pulmonary hypertension

Hussain A., Arfi A., Draz S., Abozeid H., Al-Ata J.

The right ventricular growth after decompression in patients with critical right ventricular outflow tract obstruction

Kristo I.,, Spadoni I., Vittorini S., De Lucia V.,Recla S., Lunardini A., Giusti S.

Serum Uric Acid Levels in Normotensive Children With Family History of Essential

Hypertension

Kilic Z., Tutuncu R.T., Ozdemir G., Kosger P., Ucar B., Demir T. 
P-128

P-130

P-133

$\mathrm{P}-134$

P-135

P-136

P-137

P-138

P-139

P-140

P-141

P-142

P-143

P-144

P-145

P-146

P-147

P-148

Comparison of perioperative C-reactive protein between neonates after the Norwood procedure or arterial switch operation

Yu X., Larsen B., Cheypesh A., Rebeyka I., Li J.

Is Hypoplastic Left Heart Syndrome a Disease of Aortic Valve? A Genetic Perspective Federici D., lascone M., Marcora S., Pak V, Marchetti D., Seddio F., Lincesso AR., Pezzoli L., Galletti L., Ferrazzi P.

Etiological and Clinical Aspects of Dilated Cardiomiopathy in Children in North-Eastern Romania

Luca A.C., lordache C., Moisa S.M

Alström Syndrome- a rare disease presenting with dilative cardiomyopathy and blindness.

Two case reports

Kost S., Seidel H., Balling G., Hess J.

The evaluation of the long-term effect of intrauterine malnutrition on the cardiac functions

Gurses D., Seyhan B.

Palliative Potts anastomosis for primary pulmonary hypertension in children:

mid-term results

Petit J., Baruteau A., Belli E., Houyel L., Serraf A.

Arterial Hypertension in Children in in North-Eastern Romania

lordache C, Luca A.C., Moisa S.M, Moscalu C.

Sildenafil: Experience in Children with or without Pulmonary Hypertension and Congenital Cardiac Defects

Rodríguez A., Medrano C., Panadero E., Fernandez C., Alvarez T., Vazquez M.C., Camino M., Ballesteros F., Maroto E., Zunzunegui J.L.

Patient Registry of the Competence Network for Congenital Heart Defects in Germany

Pickardt T., Abdul-Khaliq H., Asfour B., Kececioglu D., Klaassen S., Kramer H.-H., Frey M., Bauer U.

Sildenafil as preparation for the Fontan Procedure

Zunzunegui J.L., Rodriguez A., Medrano C., Panadero E., Alvarez T., Centeno M., Camino C., Maroto E., Vazquez M.C.

The PAN study: Association of Gestational and Peripartal Characteristics with Different Cardiovascular Malformations

Lindinger A., Schwedler G., Hense H.W.

Echocardiographic and electrocardiographic parameters as predictors of a worse outcome in children with hypertrophic cardiomyopathy

Ziolkowska L., Turska-Kmiec A., Boruc A., Kowalczyk M., Daszkowska-York J., Kawalec W. QTc interval in patients with non-compaction of the myocardium

Veyrier M., Teyssier G., Henaine R., Sassolas F., Ducreux C., Gouton M., Ninet J., Bozio A., Di Filippo S.

Population study of 332 consecutive newborns with HLHS - a single center experience Mazurek-Kula A., Moll J.A., Moll J.J., Sysa A.

Intima-media thickness measurements in children after end- to-end operation of coarctation of the aorta

Jagiellowicz D., Brzezinska-Rajszys G., Kawalec W., Litwin M., Niemirska A., Birbach M., Kansy $A$.

Hypoxic myocardial injury in newborn infant-diagnosis and evolution

Dimitriu A.G., Dimitriu L., Stamatin M.

Heart disease in the newborn of diabetic mother. Usefulness of echocardiographic assessment

Dimitriu A.G., Dimitriu L., Stamatin M.

Association of mitral regurgitation with anomalous left coronary artery from the pulmonary artery (ALCAPA) in children

Dhandayuthapani G, Wong J.K., Uzun O., Goc B., Parsons J.

Long- term outcome of ALCAPA. A single centre experience

Kudumula V., Stickley J., Stumper O., Barron D.J., Giovanni J., Brawn W.J., Miller P., Jones T., Dhillon R., Desai T., Chikermane A., Mehta C.

ST-segment elevation myocardial infarction (STEMI) due to severe anemia resulting from transient erythroblastopenia of childhood in a 2 year

old boy after arterial switch operation in the absence of coronary artery stenosis

Bindermann R., Vilser D., Limpert E., Kentouche K., Gruhn B., Flosdorff P., Hennig B.

The Namibian Children's Heart Project: A new cardiac service in Africa

Hugo-Hamman C, du Toit $H$, Vosloo S, Kaaya M 


\section{GUCH and outcomes}

P-149

P-150

P-151

P-152

P-153

P-154

P-155

$P-156$

P-157

P-158

P-159

P-160

P-161

P-162

P-163

P-164

P-165

P-166

P-167

P-168

Ebstein's anomaly: Rhythm disturbances after modified reconstruction of tricuspid valve without ventricle plication

Nagdyman N., Reumuth G., Ewert P., Hetzer R., Berger F.

Changing Trends in GUCH Intervention over last 10 years. A single Centre experience

Chessa M., MacDonald S.T., Negura D., Micheletti A., Piazza L., Butera G., Giamberti A., Pome G., Frigiola A., Carminati $M$.

Fallot repair in adulthood. Surgical results and medium follow-up

Aroca A., Polo L., Portela F., Cabestrero D., Bret M., Bautista V.,

Sánchez-Recalde A., Peña N., Ruiz J., González A., Villagrá F., Oliver JM.

Adult life reoperations in Fallot patients with corrective surgery during childhood

Polo L., Aroca A., Cabestrero D., González A., Bret M., Ruiz J., Pérez N.,

Sanchez-Recalde A., Oliver J., Villagrá F.

Influence of pulmonary valvulation in adults with Tetralogy of Fallot on left ventricular function Gouton M., Bakloul M., Chalard A., Boussel L., Metton O., Henaine R., Ninet J., Bozio A., Di Filippo S.

Pregnancy: tolerance and outcomes in women with Ebstein's anomaly

Gouton M., Goldman C., Bakloul M., Sassolas F., Bozio A., Di Filippo S.

Exercise capacity and self reported functional status in patients with complex congenital heart disease

Balint O.H., Majer K., Kovats A., Csepregi A., Andréka P., Szatmári A., Karlócai K., Temesvári A. The clinical implications of serum uric acid levels in adult patients with congenital heart disease

Inai K., Shimada E., Yamamura H., Shinohara T., Nakanishi T.

Clinical outcome and echographic features of patients with repaired tetralogy of Fallot and biventricular pacing

de Guillebon M., Iriart X., Bordachar P., Horovitz A., Thambo J.B.

Follow-up after Fontan Conversion

Pringsheim M., Hörer J., Schreiber Chr., Müller J., Hager A., Hess J.

Univentricular heart and body growth: are we timing the Fontan stages properly?

François K., Bové T., Panzer J., De Groote K., Vandekerckhove K., De Wilde H., Vandenberghe P., Benatar A., De Wolf D.

Magnetic resonance imaging and cardiopulmonary test in adults after repair of tetralogy of Fallot: effects of pulmonary valve replacement

Balducci A., Fabi M., Testa G., Gesuete V, Pessina A., Donti A., Montalti A., Prandstraller D., Picchio F.M., Bonvicini M., Pace C., Gargiulo G.

Activity in Adolescents with Congenital Heart Disease (CHD)

Morrison M.L., Sands A.J., McKeown P.P., Gordon J., Craig B.G., Casey F.A.

Quality of life in families with a child after staged treatment for hypoplastic left heart syndrome (HLHS)

Mazurek-Kula A., Majchrzak A., Moll J.A.

Do patients benefit from Ross procedure even in long-term?

Kantorova A., Kaldararova M., Nosal M., Hraska V., Tittel P., Vrsanska V.

Incidence and Etiology of Secondary Surgical Interventions on the Aorta in Marfan

Syndrome

Schoenhoff F., Jungi S., Czerny M., Krahenbuhl E., Reineke D., Schmidli J.,

Kadner A., Carrel T.

The outcome of Eisenmenger patients with trisomy 21 does not differ from patients without trisomy 21

Van De Bruaene A., Troost E., Lampropoulos K., Post M.C., Moons P., Delcroix M., Gewillig M., Budts W.

The long term outcome of patients with interventional treatment of pulmonary valvular atresia/stenosis

Spadoni I., Lunardini A., Kristo I., Ait-Ali L., De Lucia V., Giusti S.

Detrimental effects of chronic non-systemic ventricular pacing in patients with atrial switch for transposition of the great arteries

de Guillebon M., Horovitz A., Bordachar P., Iriart X., Bretonneau A., Roubertie F., Thambo J.B. Impaired fibrinogen function in patients with cyanotic congenital heart disease Jensen A., Johansson P.I., Bochsen L., Idorn L., Sørensen K.E., Thilén U., Nagy E., Søndergaard $L$. 
P-169

$\mathrm{P}-170$

$\mathrm{P}-171$

P-172

P-173

P-174

P-175

P-176

P-177

$\mathrm{P}-178$

P-179

P-180

P-181

$\mathrm{P}-182$

P-183

$\mathrm{P}-184$

P-185

P-186

P-187

P-188
The hematocrit - an important factor causing impaired haemostasis in patients with cyanotic congenital heart disease

Jensen A., Johansson P.I., Idorn L., Sørensen K.E., Thilén U., Nagy E., Furenäs E., Søndergaard $L$.

In operated fallot is RV end-diastolic volume $>170 \mathrm{ml} / \mathrm{m} 2$ a valid cut-off for indication to pulmonary valve replacement?

Festa P., Ait-Ali L., Molinaro S., Gnassi G., Siciliano V., Bernabei M., Passino C.

High percent of reinterventions in patients with aortic coarctation repair

Csepregi A., Balint O.H., Temesvari A., Andreka P., Szatmari A.

Quality of life of patients after percutaneous closure of atrial septal defect

Kourkoveli P., Kantzis M., Apostolopoulou S.C., Rammos S.

\section{Imaging/functional assessment}

Changes of myocardial deformation and dyssynchrony in children with hypoplastic left heart syndrome before and after the Norwood operation assessed by 2D speckle tracking Petko C., Uebing A., Furck A.K., Rickers C., Scheewe J., Kramer H.-H.

Comparison of myocardial deformation and dyssynchrony in children with left and right ventricular morphology after the Fontan operation assessed by 2D speckle tracking Petko C., Hansen J.-H., Scheewe J., Kramer H.-H.

Progressive Contractile Dysfunction After Norwood Procedure Compared to Biventricular Repair and Isolated Aortopulmonary Shunt

Gentles T.L., Cowan B., Occleshaw C., Beca J., Finucane A.K., Young A.A.

Assessment of Pulmonary Veins after Atrio-Pericardial Anastomosis by Magnetic

Resonance Imaging

Grosse-Wortmann L., Greenway S.C., Baliulis G., Caldarone C.A., Coles J., Yoo S.J.

Cardiac function after repair of tetralogy of Fallot: how are the atria performing?

Wohlmuth C., Voser E., Kellenberger C.J., Valsangiacomo Buechel E.R.

Sildenafil for successful recruitment of lost pulmonary capillaries after Fontan surgery

Celik L., Papakostas K., Lentschig M., Nürnberg J.-H.

Bi-ventricular Diastolic Function by Tissue Doppler Imaging Correlates with Severity of Pulmonary Arterial Hypertension in Children

Jone P., Howley L.W., Hinzman J., Ivy D.D., Younoszai A.

Prediction of pressure gradient in aortic coarctation by computational fluid-dynamic simulations Valverde I., Staicu C., Marzo A., Grotenhuis H., Rhode K, Tzifa A, Razavi R,

Lawford P., Hose R., Beerbaum P.

Three-dimensional echocardiographic features of parachute mitral valve

Valverde I., Rawlins D., Beerbaum P., Simpson J.

Evaluation of cardiac functions by tissue Doppler echocardiography in children with familial Mediterranean fever

Ozdemir O., Agras P.I., Aydin Y., Abaci A., Hizli S., Akkus H.I.

Measurement of Coronary Flow Velocity and Coronary Flow Reserve During Stress

Echocardiography in Pediatric Heart Transplant Patients

Toma W.S., Human D.G., De Souza A.M., Williams L.D., Hollinger A.J., Potts J.E.,

Sandor G.G.S.

Coronary flow in Neonates with Impaired Intrauterine Growth

Aburawi E.H., Malcus P., Thuring A, Fellman V, Pesonen E

Echocardiographic evaluation of left ventricular outflow tract hemodynamics in healthy

children with anomalous left ventricular band

Bjelakovic B., Ilic S., Saranac S., Chouliaras K., Parezanovic V., Vukomanovic G.

Quantifying tricuspid regurgitation of patients with congenital heart disease routinely by magnetic resonance

Rieger H., Stern H., Meierhofer C., Nerad M., Mueller D., Schuster T.,

Knesewitsch T., Seligmann M., Martinoff S., Hess J., Fratz S.

Cardiac functions in children with growth hormone deficiency before and during growth hormone replacement therapy

Ozdemir O., Abaci A., Hizli S., Razi C.H., Akelma A.Z., Kocak M., Kislal F.M.

Novel combined 'Cardiac Catheterization-Magnetic Resonance Imaging' (XMR) under dobutamine stress for cardiovascular assessment in children prior to liver transplant Valverde I., Miller O., Hadzic N., Bell A., Beerbaum P., Greil G., Heaton N., Qureshi S., Razavi R., Tzifa A. 
P-189

P-190

P-191

P-192

P-193

P-194

P-195

P-196

P-197

P-198

P-199

P-200

P-201

P-202

P-203

P-204

P-205

P-206

P-207
Detection of early cardiac dysfunction in patients with $\beta$ thalassemia major and thalassemia trait by tissue Doppler echocardiography

Gurses D., Isik Balci Y.

Exercise capacity and cardiac reserve in children with corrected pulmonary atresia with intact ventricular septum after univentricular and biventricular repair

Romeih S., Roest A.A.W.,Groenink M., van der Plas M.N., Hazekamp M.G., Spijkerboer A.M., Mulder B.J.M., Blom N.A.

Caution in the Interpretation of Z-Scores in Patients with Pulmonary Atresia with Intact Ventricular Septum

Chubb H., Qureshi S.A., Tibby S.M., Simpson J.M.

Quantitative Evaluation of the Hemodynamics in Fontan Circulation

Honda T., Itatani K., Kimura S., Nakahata Y., Miyaji K., Ishii M.

Impact of Sport and High Intensity Training on Global and Regional Myocardial Deformation in Elite High School Athletes

Lindquist R.K., Miller A.R., Hanson C.L., Johnson J.A., Johnson J.N., O'Leary P.W., Cetta F., Eidem B.W.

Value of Real - Time Three - Dimensional Transesophageal Echocardiography in

Assessment and Percutaneous Closure of Multiple Atrial Septal Defects

Arcidiacono C., MacDonald S.T., Piazza L.P., Micheletti A., Negura D.G., Butera G.,

Chessa M., Carminati $M$.

Tissue Doppler imaging in healthy children: normal systolic velocities, timings, and time differences in left ventricle and right ventricle

van der Hulst A.E., Delgado V., Ten Harkel A.D.J., Klitsie L.M. Filippini L.H.P.M., Bax J.J., Blom N.A., Roest A.A.W.

Branch Pulmonary Arterial Phase-Contrast MRI to detect pulmonary venous baffle

obstruction after atrial switch procedure

Miles C., Hussain T., Bell A., Razavi R., Beerbaum P., Tzifa A., Botnar R., Greil G.

Is exercise capacity of adults with repaired tetralogy of Fallot affected by type of repair? Kantzis M., Kourkoveli P.E., Apostolopoulou S.C., Rammos S.

Is New York Heart Association classification an appropriate tool for the functional evaluation of patients after total repair of Tetralogy of Fallot?

Kourkoveli P.E., Kantzis M., Apostolopoulou S.C., Rammos S.

Right Ventricular Mechanical Dyssynchrony is Associated with Tricuspid Regurgitation in Children with Hypoplastic Left Heart Syndrome

Bharucha T., Khan R., Mertens L., Friedberg M.K.

Optimizing ECG-triggering during cardiovascular magnetic resonance and its impact on blood flow quantification in patients with congenital heart disease

Knesewitsch T., Meierhofer C., Rieger H., Seligmann M., Schneider P., Lyko C., Steinlechner E., Rößler J., Frank M., Nerad M., Martinoff S., Hess J., Stern H., Fratz S.

Serial follow-up of biventricular function, contractile reserve, exercise capacity, and NTproBNP measurements in repaired tetralogy of Fallot

Luijnenburg S.E., van den Berg J., Moelker A., Roos-Hesselink J.W., Bogers A.J.J.C., de Rijke Y.B., Mulder B.J.M., Vliegen H.W., Helbing W.A.

Right ventricular function is impaired one week after corrective surgery of an atrial septal defect

Klitsie L.M., Hazekamp M.G., Gesink B.J., Kuipers I.M., Blom N.A., Ten Harkel A.D.J. Shortly after corrective surgery of a ventricular septal defect right ventricular function is impaired and the level of impairment is correlated with cardiopulmonary bypass time Klitsie L.M., Hazekamp M.G., Gesink B.J., Kuipers I.M., Blom N.A., Ten Harkel A.D.J. Ventricular function is impaired shortly after corrective surgery of a congenital heart defect Klitsie L.M., Hazekamp M.G., Gesink B.J., Kuipers I.M., Blom N.A., Ten Harkel A.D.J. Decreased global myocardial function in infants with hypoplastic left heart syndrome (HLHS) is associated with missed intrauterine diagnosis, longer operative times and lower postoperative systemic blood pressure values

Markkanen H., Pihkala J., Salminen J., Jokinen E., Sairanen H., Ojala T.

Obesity is responsible for increased blood pressure, left ventricular thickness and tension leading to early impairment of diastolic function

Tissot C., Wacker J., Farpour-Lambert N., Golay E., Aggoun Y., Maggio A., Beghetti M. Interest of three-dimensional echocardiography for the assessment of bicuspid aortic valve in children

Séguéla P.E., Sadron M., Arnaudis B., Dulac Y., Acar P. 
P-208

P-210

P-214

P-215

P-216

P-217

P-218

P-219

P-220

$\mathrm{P}-221$

P-222

P-224

P-225

P-226

The role of transesophageal echocardiography in a tertiary congenital heart centre: retrospective study on 1045 consecutive examinations Pringsheim M., Röhlig Chr., Kühn A., Vogt M., Hess J.

The Impact of Flat-detector computed tomography during Catheterization of congenital Heart Disease

Glöckler M., Greim V., Koch A., Toka O., Breuer C., Rüffer A., Cesnjevar R., Dittrich S.

Evaluation of the ventricular functions in the obese children by tissue Doppler echocardiography

Gurses D., Ozyurek A.R., Ulger Z., Levent E, Coker M., Darcan S.

Change in left ventricular vortex flow before and after surgery for coarctation of the aorta in an infant shown with plane wave imaging and flow speckle tracking

Nyrnes S.A., Lovstakken L., Torp H.,Haugen B.O.

Echocardiographic evaluation of pulmonary vascular resistance and reactivity in children with pulmonary hypertension

Cevik A., Kula S., Tunaoglu F.S., Oguz A.D.,Olgunturk R., Pektas A.

Role of speckle strain for evaluation of ventricular function after Total Cavo-Pulmonary

Connection: does it identify patients at risk?

Vikllar A.M., Banaudi E., Riggi C., Marini D., Agnoletti G.

Right ventricular volumes and function assessed by three-dimensional echocardiography in children with surgically corrected Tetralogy of Fallot and their healthy controls: Comparison to cardiac MRI

Ylitalo P., Pitkänen O., Lauerma K., Holmström M., Jokinen E.

Visualization of the Intracavitary Blood Flow in Systemic Ventricles of Fontan Patients by Contrast Echocardiography Using Vector Particle Velocimetry

Van De Bruaene A., Konstantinos L., van Melle J.P., Troost E., Voigt J.U.,

Gewillig M., Budts W.

The functional right ventricle in patients with Ebstein's anomaly is not small

Nerad M., Mueller D., Buchner C., Rieger H., Steinlechner E., Meierhofer C., Martinoff S., Hess J, Stern H., Fratz S.

Pulmonary and systemic vascular resistance in patients with open and closed ASD type secundum

Van De Bruaene A., Hermans H., Delcroix M., Voigt J.U., Gewillig M., Budts W.

The Coronary Arteries in Patients with Hypoplastic Left Heart

Syndrome - An Angiographic Study and its Clinical Implications

Hansen J.H., Uebing A., Scheewe J., Kramer H.-H., Fischer G.

Changes in Myocardial Velocities in First week of life in Pre Term Infants

Armstrong K., Molloy E., Franklin O.

Detection of right ventricular fibrosis by CMR and plasma levels of procollagen type III

$\mathrm{N}$-terminal amino peptide in patients with Tetralogy of Fallot

Ylitalo P., Pitkänen O., Lauerma K., Holmström M., Jokinen E.

Correlation of the right atrial volume with the right ventricular end-diastolic pressure

Binder W., Apitz C., Bretschneider C., Seeger A., Martirosian P.,

Kramer U., Hofbeck M., Sieverding L.

Exercise testing coupled with Doppler echocardiography : a simple, safe and effective method to assess the severity of coarctation of the aorta

Ngayap Nemkam H., Houyel L., Leborgne-Meyer A.S., Stos B., Serraf A., Zeitouni R.

New magnetic resonance imaging indexes for the evaluation of elastic properties of aortic wall in patients with bicuspid aortic valve

Festa P., Ait-Ali L., De Marchi D., Levorato Basso M., Lombardi M., Pingitore A, Aquaro G.D.

Tissue Doppler Imaging combined with advanced 12-lead ECG analysis might improve early diagnosis of hypertrophic cardiomyopathy in childhood

Fernlund E., Schlegel T., Liuba P.

2D Speckle Tracking assessment of left ventricular torsion in healthy children and heart transplants

Vázquez-Álvarez M.C., Medrano-López C., Camino-López M., Granja da Silva S., Marcos-Córdova C., Carvajal del Castillo O., Rodríguez Ogando A., Centeno-Jiménez M., Maroto-Álvaro $E$.

Coronary arteries originating from the opposite coronary cusp: diagnosis and long term outcome

Bozio A., Ninet J., Boussel L., Henaine R., Sassolas F., Ducreux C., Gouton M., Metton O., Bakloul M., Veyrier M., Pangaud N., Di Filippo S. 
Dobutamine stress echocardiography in the assessment of postoperative left ventricular function in children after arterial switch operation for transposition of great arteries Ostrowska K., Moll J.A., Sysa A.

RV-dysfunction-Does it affect left ventricular torsion?

Laser K.T., Hauffe P., Aslan I., Uges G., Körperich H., Beck C., Haas N., Sandica E.,

Kececioglu $D$. $\begin{array}{ll}\text { P-229 } & \text { Benefits for patients with CHD in } 3.0 \text { Tesla MR Imaging with MultiTransmit Technology - First } \\ & \text { Experience } \\ & \text { Laser K.T., Gieseke J., Esdorn H., Peterschröder A., Barth P., Kececioglu D., Burchert W., } \\ & \text { Beck C., Körperich H. } \\ & \text { 3D Wall Motion Tracking: Our Experience in Healthy Children and Congenital Suprarrenal } \\ & \text { Hyperplasia }\end{array}$

Marcos-Córdova C., Huidobro B., Vázquez-Álvarez M.C., Granja da Silva S., Rodríguez Ogando A., Rodríguez M.D., Maroto-Álvaro E., Medrano-López C.

Congenital heart defect specific volumetric data in children with Hypoplastic Left Heart Syndrome measured by CMR

Hart C., Pardun E., Voges I., Gabbert D., Jerosch-Herold M., Hansen T., Kramer H.-H., Rickers $C$. measurement of ventricular end-diastolic pressure (EDP) in biventricular rather than univentricular physiology in patients with congenital heart disease (CHD) Abdul-Khaliq H., Mi Y.P.

The novel 2D strain reflects improvement and remodelling of LV function rather the conventional echo parameter after aortic valve repair in pediatric patients

Abdul-Khaliq H., Mi Y., Rädle-Hurst T., Schäfers H.-J.

Assessment of Standard and Non- Standard Echocardiographic Acoustic Windows to Visualize the Right Ventricle in patients with Tetralogy of Fallot

Waiss M.-P., Mertens L., Ge S.

\section{Interventional cardiology}

Transcatheter closure of patent ductus arteriosus (PDA): Comparison of Amplatzer duct occluder with the new Amplatzer duct occluder II Oswal N., Khambadkone S., Derrick G., Yates R.

Ventricular Septal Defects Closure by Transcatheter Patch in patients with Down Syndrome Zanjani K.S., Zeinaloo A., Macuil B., Sideris E.

Acute Heart Failure after Percutaneous Pulmonary Valve (Melody $@$ Valve) Placement

Hagler D.J., Taggart N.W., Connolly H.M.

Interventional catheterisation after total cavopulmonary connection: experience in 68 patients Marini D., Banaudi E., Riggi C., Villar A., Agnoletti G.

Obstruction of systemic veins: early and medium term results of percutaneous interventions Marini D., Gabbarini F., Riggi C., Villar A., Agnoletti G.

Dilatation of pulmonary artery stenosis and coarctation of the aorta with new Cobalt-

Chromium Stents (Andrastents XL \& XXL)

Fiszer R., Szkutnik M., Bialkowski J.

Stent implantation in aortic coarctation in children: ten year experience

Butera G., Marini D., Heles M., Piazza L., Chessa M., Micheletti A., Negura D., Arcidiacono C., Fesslova V., Bussadori C., Carminati $M$.

Transcatheter Closure of Perimembranous Ventricular Septal Defects Using the Amplatzer Perimembranous Ventricular Septal Defect Occluder in Children: Initial and 4-year Results. A Multicenter Study

Thanopoulos B.D, Rigby M.L., Karanasios E., Blom N., Stefanadis C.H., Giannakoulas G., Tsaoussis G.

Percutan
children 
P-246

P-248

P-249

P-250

P-252

P-253

P-255

P-256

P-257

P-258

P-259

P-260

P-261

P-262

P-263

P-264

P-265

Follow-up results of transcatheter pulmonary valvotomy in patients with pulmonary atresia and intact ventricular septum

Wang J.K., Wu M.H., Lin M.T., Chiu S.N., Chen C.A.

Re-Interventions in pulmonary arteries during the classical Fontan palliation pathway

Gitter R., Leitner-Peneder G., Steiner J., Sames-Dolzer E., Mair R., Tulzer G.

Right heart failure due to an acute obstructing fracture of a Melody $($ valve stent

Gitter R., Mair R., Prandstetter Ch., Tulzer

Use of a Telescopic System for Transcatheter Radiofrequency Perforation and Balloon

Valvotomy in Infants with Pulmonary Atresia and Intact Ventricular Septum

Tuo G., Bondanza S., Serafino M., Petrucci L., Zannini L., Marasini M.

Morphology of patent ductus arteriosus; a predictor of the outcome of stenting in

duct-dependent pulmonary circulation an experience in children hospital,

cairo University, Egypt

Agha H., Hamza H., Esmat A., Hussein Y., Shawky H., Hassanein H., El Sayad T.

17 years follow up after interventional treatment of aortic valve stenosis in newborns and infants less than six month

Kaestner M., Geisler J., Toussaint-Goetz N., Schneider M.B.E.

Incidence of atrial fibrillation after percutaneous closure of patent foramen ovale in patients presenting with cryptogenic stroke

Testa G., Gesuete V., Donti A., Formigari R., Sacchetti V., Montalti A., Balducci A., Fabi M., Bonvicini M., Picchio F.M.

Results of intervetional procedures in children with aortic arch hypoplasia or stenosis after coarctation surgery

Werynski P., Rudzinski A., Krol-Jawien W., Kuzma J.

Balloon valvuloplasty for critical aortic stenosis in neonates-long term follow-up

Szatmári A., Ablonczy L., Környei L.

Combined X-ray and MRI-guided cardiac catheterisations (XMR): clinical impact in patients with complex anatomy or raised pulmonary vascular resistance

Tzifa A., Bell A., Beerbaum P., Charisopoulou D., Greil G., Valverde I., Bellsham-Revell H., Hussain M., Mahtani D., Qureshi S.A., Razavi R.

Use of a modern cardiac catheterisation laboratory greatly reduces radiation dose during structural interventions

Smith B., Krasemann T., Rosenthal E., Qureshi S.

Innovation: Catheter Interventions in Congenital Heart Disease without Catheterization Laboratory Equipment, The Chain of Hope Experience in Rwanda

Guillaume M.P., Senga J., Rusingiza E., Mucumbitisi J., Carbonez K., Ovaert C., Suys B., Sluysmans $T$.

Midterm follow up of interventional closure of atrial septal defect using the Solysafe ${ }^{\mathrm{TM}}$

Septal Occluder - Diagnostic impact of fluoroscopy for complication management

Knirsch W., Quandt D., Dave H., Pretre R., Kretschmar O.

Cyanosis due to right-to-left interatrial shunt without pulmonary artery hypertension.

Transcatheter occlusion in 63 consecutive patients

Godart F., Bouallal R., Francart C.

Midterm follow-up after interventional closure of atrial septal defects using the Solysafe

septal occluder

Koch A., Glöckler M., Breuer C., Toka O., Dittrich S.

Right ventricular outflow tract stenting in very low birth weight newborns

Krings G., Freund M.W., Strengers J., Breur H., Opgen-Rhein B., Berger F.

Pulmonary Atresia and Intact IV Septum (PA intact IVS) after Successful transcatheter

Valvotomy. Impact in right ventricular growth. Additional devices and surgical procedures in 10 years follow up

Mortera C., Bartrons J., Rissech M., Prada F., Jimenez L., Carretero J., Brugada J.

Interventional treatment of aortic coarctation in neonates and infants-one

centre results

Dryzek P., Goreczny S., Moszura T., Politowska B., Moll J.A., Sysa A.

Percutaneous stent implantation in right ventricle outflow tract obstruction - single centre experience

Goreczny S., Dryzek P., Moszura T., Mazurek-Kula A., Moll J.A., Sysa A.

Extension of indications for percutaneous pulmonary valve implantation in native right ventricule outflow tract : should all patients be considered?

Van Aerschot I., Sarquella-Brugada G., Iserin L., Fraisse A., Boudjemline Y. 
P-266

P-267

P-268

P-269

P-270

P-271

P-272

P-273

P-274

P-275

P-276

P-277

P-278

P-279

$\mathrm{P}-280$

$\mathrm{P}-281$

P-282

P-283

P-284

P-285

Sutureless anastomosis with covered stents during hybrid surgery for rescue of hypoplastic - distal intrapulmonary arteries

Cools B., Louw J.J., Heying R., Vanagt W., Eyskens B., Boshoff D.E., Rega F, Meyns B., Gewillig M.

Relief of Left Pulmonary Artery stenosis with stent implantation in children with Single Ventricle Malformation prior to Fontan

Ballesteros F., Zunzunegui J.L., Vazquez M.C., Alvarez T., Granja da Silva S., Centeno M, Maroto $E$.

Stent coarctation repair in older children and adults. Single group experience and long term follow up

Abelleira C., Herraíz I., Sanchez I., Gomez R., Solana R., Perera C., Goicolea J., Tefera E., Mullins CE., Bermúdez-Cañete R.

Late complications after Interventional Closure of Atrial Septal Defect with the Solysafe $\mathbb{R}$

Septal Occluder

Djukic M., Dähnert l., Stefanovic I, Parezanovic V, Ilisic T., Vukomanovic G., Ilic S., Kovacevic

P., Jovanovic I.

Percutaneous pulmonary valve implantation (Melody ${ }^{\circledR}$ valve) in the failing pulmonary valved Contegra $\AA$ conduit in children and young adults

Beck C., Laser K.T.,Kececioglu D.,Haas N.

Detachable coils versus Amplatzer Duct Occluder devices in transcatheter treatment of small-to-medium sized Patent Ductus Arteriosus: an analysis of costs and results Lunardini A., Recla S., Ait-Ali L., De Lucia V., Giusti S., Spadoni I.

Two Melodies in Concert: catheter-interventional double valve replacement

Jux C., Billinger K., Bauer J., Valeske K., Akintuerk H., Schranz D.

Our experience in comparing Amplatzer duct occluders I and II

Narayanan A., Shauq A., Mehta C., Gladman G., Peart I., Ladusans E.

Safety and Efficacy of Catheter Interventions in Premature Infants Under $2 \mathrm{~kg}$

Radtke W.A.K., Bandisode V.M., Bradley S.B., Pizarro C

Results of endovascular stenting of coarctation of the aorta in 189 patients - Polish registry Brzezinska-Rajszys G.,, Bialkowski J., Szkutnik M., Zubrzycka M., Sabiniewicz R., Dryzek P. Percutaneous Closure of "tunnel shaped" ventricular septal defect using the Amplatzer Vascular Plug II in pediatric patient

D'Andrea C., Donti A., Formigari R., Testa G., Gargiulo G.D., Picchio F.M.

Results of transcatheter balloon aortic valvuloplasty in 59 neonates - one center experience Rewers B., Brzezinska-Rajszys G., Zubrzycka M., Ksiazyk J., Daszkowska J., Mrowiec L.

Catheter Rehabilitation of Occluded Aberrant Right Pulmonary Artery

Ramchandani B., Noonan P.M.E., Rao S., Stumper O.

A Novel Technique for Stenting Pulmonary Artery and Conduit Bifurcation Stenoses

Noonan P., Bhole V., Anderson B., Reinhardt Z., Mehta C., Stumper O.

The Three-dimensional Morphological Changes of tricuspid Valve in Children after

Transcatheter Closure of Atrial Septal Defect

Inoue N., Yasukochi S., Takigiku K., Matsui H., Watanabe S., Mori H., Morimoto Y.

\section{Surgery and Intensive care}

A twenty Year Experience of Arterial Switch Repair by Direct Anastomosis Retaining a Normal Position of the Pulmonary Bifurcation

Ahmed A., Hong Lee L., Sands A., Casey F., Craig B., Gladstone D.

Risk Factors in Neonatal Cardiac Surgery

Trunina I.I., Tumanyan M.R., Filaretova O.V., Anderson A.G., Kharkin A.V.,

Abramyan M.A.

Correlation of near-infrared spectroscopy (NIRS) with cardiac index in infants following surgery for congenital heart disease

Gil-Anton J., Morteruel E., Redondo S., Nieto M., Garcia D., Fernandez J.

Cardiac output and intrathoracic volumetric parameters obtained by ultrasound dilution and transpulmonary thermodilution methods in a pediatric animal model

Boehne M., Schmidt F., Witt L., Köditz H., Sasse M., Seidemann K., Sümpelmann R., Wessel A., Osthaus W.A.

Intravenous beta1-receptor blocking medication as a rescue treatment for severe

postoperative myocardial diastolic dysfunction in infants

Furck A.K., Desai A., Rodrigues W., Macrae D., Slavik Z. 
P-286 Is oral enoximone a safe alternative to protracted intravenous medication in severe myocardial failure in children?

Age impacts on outcomes of children on mechanical ventricular support

Henaine R., Berthomieu L., Bastien O., Ninet J., Bozio A., Sassolas F., Ducreux C., Gouton M., Veyrier M, Bakloul M., Di Filippo S.

Beyond Adenosine: Use of Dexmedetomidine in a New Approach for the Termination of Reentrant Supraventricular Tachycardia

Chrysostomou C., Sanchez de Toledo J., Morell V.O., Wearden P., Wiesen E., Yoshida M., Beerman L., Orr R., Munoz R. of our management without compromising patient safety?

Marcos-Alonso S., Ávila A., Diaz R., Fernández J.L., Ferrer A., Garciá I., González I., Rodríguez B., Taboada M, Vergara I., Rueda F.

Surgical Correction of HOCM in Young Patients with Severe Hypertrophy

Borisov K.V.

Cerebral Magnetic Resonance Imaging before and after Neonatal Cardiac Surgery for severe Congenital Heart Disease

Knirsch W.,, Batinic K., Liamlahi R., Makki M., Kellenberger C., Scheer I., von Rhein M., Schmitz A., Bernet V., Hug M.I., Dave H., Latal B.

Differences in Plasma B-type natriuretic peptide levels in children with univentricular heart malformation undergoing Fontan procedure

Knirsch W., Häusermann E., Prêtre R., Dave H., Kretschmar O.

Hemodynamic consequences of postoperative inflammation after pulmonary valve replacement

Koch A., Glöckler M., Seitz S., Rüffer A., Cesnjevar R., Dittrich S.

Need of ECMO in a reversible life-threatening plastic bronchitis 8 years after Fontan completion

Ruf B., Balling G., Reiter K., Hess J. (d-TGA) - clinical significance after arterial switch operation Unfavourable Outcome?

Kasnar-Samprec J., Hörer J., Bierwirth H., Prodan Z., Cleuziou J., Eicken A., Lange R., Schreiber $C$. CPB-supported ECFO

Sohn C., Redlin M., Schmitt K., Hübler M., Alexi-Meskishvili V., Hetzer R., Berger F., Ovrutskiy S. 
Oral sildenafil early after Fontan operation improves postoperative outcome

Ovrutskiy S., Behrbohm S., Miera O., Hübler M., Nagdyman N., Peters B,

Ewert P., Berger F.

P-306

Levosimendan in dilated cardiomyopathy and refractory cardiogenic shock in children

Mouton J.B., Seban L., Mauriat P., Thambo J.B.

P-307

Chylothorax - do standard management techniques affect prolonged pleural drainage in post-operative cardiac surgery patients?

Smith R., Adhvaryu K., Holmes V., Johnson R.A.

P-308

Sildenafil Treatment in the Postoperative Stage I and II in Univentricular Circulation

Rodriguez A., Zunzunegui J.L., Medrano C., Panadero E., Fernandez T., Rodríguez M.J., Fernadez C., Vázquez M.C., Centeno M., Álvarez T., Ballesteros F., Maroto E.

Survival and catheter interventions after Norwood surgery

Bertels R.A., Rijlaarsdam M.E., Bökenkamp R., Hazekamp M.G., Blom N.A. 
Dear Friends and Colleagues,

We look forward to welcoming you to the 45 th Annual Meeting of the Association for European Paediatric Cardiology, being held in the fascinating city of Granada at the foot of the Sierra Nevada mountains. This modern and lively city houses many splendid historical monuments.

For the annual meeting, we have received a total of 704 abstracts this year. A large panel of expert reviewers has accepted approximately one half of these to be presented. You will find the accepted high-quality abstracts in this book. We hope that this book will help you follow the discussions during the meeting and gives a good overview of the issues that are currently the hot topics in the research of congenital cardiology. In addition, there will be three prizes for the best posters. As in previous years, junior participants will receive special consideration. An AEPC Young Investigator's award and one JSPCCS Young Investigator's Award will be given. All the prizes will be distributed during the Social Evening of the meeting.

The programme of the meeting deals with the volume-loaded right ventricle, pulmonary atresia with intact ventricular septum and with ventricular septal defect and aorto-pulmonary collaterals and various imaging modalities. Pulmonary hypertension and management of arrhythmias in children will also be discussed in detail. Together with JSPCSS, AEPC has organised a meeting on complex left ventricular outflow tract obstruction. There will also be a session focused on cardiac imaging during interventions. A panel of experts will discuss controversies in relation to and long-term follow-up after the arterial switch operation. Other major topics discussed during the sessions include the daily management of patients in paediatric cardiac intensive care unit and quality of care. The session on successes and failures in the catheterization laboratory will once again be interactive and informative. This year, there will be two anatomic exhibitions dealing with cardiac anatomy for interventionists and anatomy of left and right ventricular outflow tract diseases.

Granada with its Moorish history and its prestigious university and the atmosphere of old cultures and sciences awaits your attendance. We hope that you will enjoy the high quality scientific programme that gives an excellent update of new developments in Paediatric Cardiology. The Annual meeting creates a fruitful environment for active scientific discussions and gives a splendid opportunity to meet colleagues and experts form all around the world.

Granada, May 16, 2011

Shak Qureshi AEPC President

Eero Jokinen

AEPC Secretary-General 